\title{
Pain Relief, Prescription Drugs, and Prosecution: A Four-State Survey of Chief Prosecutors
}

Stephen J. Ziegler and Nicholas P. Lovrich, Jr.

$\mathrm{T}$ he experience of having to suffer debilitating pain is far too common in the United States, and many patients continue to be inadequately treated by their doctors. Although many physicians freely admit that their pain management practices may have been somewhat lacking, many more express concern that the prescribing of heightened levels of opioid analgesics may result in closer regulatory scrutiny, criminal investigation, or even criminal prosecution.

Although several researchers have examined the regulatory environment and the threat of sanction or harm it poses to physicians and patients, few have examined the likelihood of investigation or prosecution stemming from the aggressive use of opioids in physician-directed pain management. Accordingly, in an effort to assess whether the fear of prosecution is realistic and, if so, what factors contribute to its likelihood, we surveyed chief prosecutors in four states about their knowledge, opinions, and attitudes concerning opioids and the prosecution of physicians stemming from the treatment of patients who were either terminally ill or suffering from chronic noncancer pain.

Before presenting these results, we begin with the medicolegal and political background of pain treatment. We then examine the thinking of American prosecutors generally at the local level, highlighting their discretion to investigate and to prosecute, and discuss the white-collar crime literature, which helps explain the inherent difficulty associated with both the detection and successful prosecution of medical crimes. Finally, we discuss the methodology and results of our survey and draw out some of the principal implications.

Journal of Law, Medicine \& Ethics, 31 (2003): 75-100. (C) 2003 by the American Society of Law, Medicine \& Ethics.

\section{The Medicolegal and Political Background}

Debilitating pain has reached epidemic proportions in the United States and continues to be neglected and inadequately treated. ${ }^{1}$ In fact, a recurring theme in the professional and lay literature concerns the undertreatment of pain and the underdispensing of opioid analgesics for both terminally ill and noncancer chronic pain patients. ${ }^{2}$ Two of the most prominent reasons for the underdispensing of opioids stem from the fear of iatrogenic addiction and increased regulatory scrutiny. ${ }^{3}$ However, the use of opioids in the management of pain is a legitimate and recognized protocol; ${ }^{4}$ the rate of addiction is very low; 5 and doctors who prescribe opioids for extended periods are "acting within the professional practice of medicine." In fact, the frequency, amount, and chronicity of opioid prescriptions are not particularly indicative of inappropriate treatment protocols. Without considering the individual patient, these aspects of dispensing practice are not determinative of abuse or diversion. ${ }^{7}$ The physician is not limited to the prescribing levels that appear on the package insert or the companion Physicians' Desk Reference (PDR); ${ }^{8}$ and a physician who is authorized to prescribe opioids may do so as long as it is for a legitimate medical purpose and the physician observes the procedures of good medical practice. ${ }^{9}$

\section{Insufficient knowledge}

Notwithstanding the above, state medical boards lack sufficient knowledge about pain management, and health care professionals sometimes overestimate the level of regulatory scrutiny to which they are exposed. In fact, studies of physicians, pharmacists, and medical regulators not only document serious gaps in knowledge, but provide evidence that many medical professionals are largely unaware of the positive role of opioids in the treatment of pain. ${ }^{10}$ Below, we briefly review the medicolegal research as it relates to the knowledge 
and concerns held by physicians, pharmacists, and medical board members in the context of pain relief and opioid use. Following this discussion, we turn our attention to prosecutors and the inherent difficulties of prosecuting medical professionals, topics that provide the background for the study reported here.

Although many physicians admit that their pain management practices may be lacking, they nevertheless fear that the dispensing of heightened levels of opioids for their patients suffering from pain will result either in negative patient outcomes or in heightened scrutiny from their medical licensing boards, county prosecutors, or even the federal government. ${ }^{11}$ For instance, several studies have indicated that physicians are often reluctant to prescribe opioids out of fear of iatrogenic addiction, ${ }^{12}$ despite the fact that the documented rate of addiction is extremely low. ${ }^{13}$ Moreover, they are also concerned that their prescribing practices will raise suspicions of pharmaceutical diversion. ${ }^{14}$ In fact, in a recent survey of Texas physicians, 26.4 percent of the respondents agreed with the following statement: "Prescribing narcotics for patients with chronic pain is likely to trigger a drug enforcement agency investigation"; and 47.7 percent agreed with the statement: "If I follow the same prescribing practices as other doctors in my field, I will not be investigated by a regulatory agency." ${ }^{15}$ But as noted earlier, chronic pain is undertreated, and the amount of opioids that are clinically indicated for a patient is highly individualized. A dosage that works for one patient suffering from chronic pain or for a patient near the end of life may be wholly inappropriate for another, particularly when considering the length of treatment, the patient's underlying illness or condition, and the pharmacokinetics of opioids. ${ }^{16}$

\section{Pharmaceutical diversion}

Physicians and medical boards alike are concerned about the diversion of controlled substances. While pharmaceutical diversion is part of a larger national drug abuse problem, the "perception of regulatory risk far exceeds the reality." ${ }^{17}$ In fact, only a relatively small percentage of prescription drugs are actually diverted to illicit use by doctors or patients. ${ }^{18}$ Notably, of the four types of offenders involved in pharmaceutical diversion, deceptive patients are far and above the most likely source of diverted pharmaceuticals; ${ }^{19}$ dated doctors (those who are out of touch or lax in their prescribing behavior) are a distant second, followed by impaired doctors. ${ }^{20}$ Dishonest doctors are the least likely source of diversion, accounting for less than 2 percent of all pharmaceutical diversion. ${ }^{21}$

\section{Fear of investigation or prosecution}

Although state medical boards appear to accept the use of opioids in larger doses over longer periods of time for termi- nally ill patients, some physicians fear investigation or prosecution for aggressively treating the pain of their terminally ill patients, particularly those near the end of life. Surprisingly, physicians who treat the terminally ill concern themselves not only with many of the same issues that arise when treating chronic noncancer pain, but also with the possibility that their actions could be misconstrued as physician-assisted suicide or euthanasia should their patients expire during the course of aggressive palliative care. ${ }^{22}$ This may especially be the case when a dying patient is suffering from severe and intractable pain and distress, and terminal sedation may be indicated. ${ }^{23}$ Briefly stated, terminal sedation involves the administration of a combination of sedatives and analgesics until the patient is palliated to the point of unconsciousness. ${ }^{24}$ Often, medically provided nutrition and hydration is withdrawn or withheld at this point. ${ }^{25}$ Eventually, whether the result of the underlying condition, the withholding of artificial nutrition and hydration, the effects of the medication, or a combination thereof, the patient expires.

While opioids are often effective for the treatment of pain in terminally ill patients, opioids such as morphine do carry the risk of respiratory depression and death. ${ }^{26}$ However, this risk is small and often limited to opioid-naïve patients..$^{27}$ In fact, pain is a natural antagonist, and an acquired tolerance is to be expected. ${ }^{28}$ Consequently, increases in dosage can occur without increased risk of respiratory depression. ${ }^{29}$

Even should a death be attributable to the use of opioids for pain relief in the dying patient, the aggressive treatment of pain is supported by the ethical principle of "double effect." Under this principle, "a proportionately good effect (relief of suffering) may overcome a foreseeable bad effect (causing death) as long as the [doctor] did not intend to accomplish the bad effect." ${ }^{30}$ Although an ethical principle, it is fair to say that the principle is now one of medical custom and standard of practice. In fact, the U.S. Supreme Court has endorsed this ethical principle and may have even created a defense to prosecution should a terminally ill patient die during the administration of palliative care. See Vacco $v$. Quill, 521 U.S. 793 (1997). ${ }^{31}$ Aside from the administration of palliative medicine, the withdrawal of medically provided nutrition and hydration during terminal sedation, if done in compliance with state law, arguably raises no separate legal or ethical issues. ${ }^{32}$

\section{Physician's intent: Who decides?}

But if a terminally ill patient expires shortly after the administration of opioids, at what point does aggressive pain relief become a violation or suspected violation of law that would justify prosecutorial review and action? If the distinction between aggressive pain relief and hastened death is a point of contention among physicians and ethicists, ${ }^{33}$ what can we 
expect from prosecutors who are likely less knowledgeable about pain relief and end-of-life care? For instance, some scholars have argued that the use of "risky analgesics" in palliative care could incur criminal liability, ${ }^{34}$ while others argue that the practice of terminal sedation is more akin to euthanasia and affords less protection than regulated physician-assisted suicide. ${ }^{35}$ But under the principle of double effect, a key in distinguishing between aggressive palliative care and euthanasia remains one of intent. ${ }^{36}$ Intent, however, often escapes exacting proof. In fact, recent attempts at legislation in the area of opioid use and terminally ill patients were unsuccessful, in part, because of opponents' concerns regarding the difficulty in determining intent. ${ }^{37}$ In the end, it is the prosecutor who must decide if criminal intent exists and whether the physician should be charged with a crime. ${ }^{38}$

\section{OuR Focus}

Earlier research focused on the fears and knowledge commanded by physicians, pharmacists, and members of state medical boards relating to the use of opioids in the treatment of pain. Our research focuses on the knowledge and attitudes of local prosecutors. In addition to directly and indirectly assessing prosecutors' knowledge, we also seek to determine whether physicians' fear of investigation or prosecution is based on an accurate assessment of reality.

Research on the frequency of prosecution stemming from the aggressive treatment of pain for terminally ill patients has been problematic. Relying on published reports of health-provider prosecutions does not present an accurate picture, for example. ${ }^{39}$ Consequently, we were curious about whether prosecutions involving physicians were more common than what was being reported. Accordingly, we build on earlier research by Ann Alpers $(1998)^{40}$ and Meisel, Jernigan, and Youngner (1999), ${ }^{41}$ and also incorporate the social science literature concerning prosecutorial discretion and white-collar crime. ${ }^{42}$ This literature not only assisted us with instrument construction and data analysis, it also provided insight into the frequency and likelihood that incidents involving physicians and pain management would be investigated or prosecuted at the local level.

Finally, our research involving local prosecutors ${ }^{43} \mathrm{dem}$ onstrates that a prosecutor's decision to investigate or prosecute amounts to policymaking in general, ${ }^{44}$ and health policy in particular. ${ }^{45}$ Consequently, this study assesses what prosecutors' policy views are in the context of pain relief and prescription drugs. Because it would be virtually impossible to determine the likelihood of prosecution without regard to the people and dynamics in the administration of justice, our next section focuses on prosecutors in general and local prosecutors in particular.

\section{Studies of Prosecutors and Prosecutions}

The American prosecutor is a unique political actor in our system of justice. Most local prosecutors in the United States are elected to office and serve in rather rural environments. ${ }^{46}$ Not only do they have multiple titles — ranging from district attorney to state's attorney - they also tend to carry out multiple roles. ${ }^{47}$ For instance, as an attorney, the prosecutor is an officer of the court who must abide by the law. ${ }^{48}$ As an elected official, the prosecutor is often directly answerable to no one except the electorate, and may seek reelection or use his or her office "as a stepping stone to more prestigious governmental positions." ${ }^{\prime 9}$ Moreover, as an elected official, prosecutors are more likely to be influenced by the community, public opinion, and influential citizens who work to ensure that prosecutors' decisions "reflect community values." ${ }^{50}$ In fact, according to Joan Jacoby, "the single most powerful influence on the prosecutor, his role, and the operations of his office is the nature of the population he represents, its resources, and the consequent social and cultural patterns it develops. ${ }^{" 1}$ She also notes that a prosecutor's

policy determinations should be and probably are influenced by the socioeconomic characteristics of the community and its value system. Since the prosecutor is a result of the local political process, his policy about enforcement of the law should reflect the opinions of the community at large..$^{52}$

The prosecutor also serves as a member of the executive branch and is vested with the authority to investigate crimes, charge offenders, offer immunity agreements, engage in plea bargains, oppose pretrial release, seek convictions, and decide what position to take concerning the sentencing of those convicted.$^{53}$ In fact, the power of the American prosecutor is so wide-ranging that former U.S. Supreme Court Justice Robert H. Jackson once remarked that a "prosecutor has more control over life, liberty, and reputation than any other person in America." ${ }^{54}$

\section{The decision to charge a suspect with a crime}

Of the many decisions that a prosecutor must make, the decision to charge a person with the commission of a crime remains one of the foremost exercises of discretion afforded the modern-day prosecutor. ${ }^{55}$ Because each case features a unique set of factual and legal issues, a prosecutor has virtually unfettered discretion to pursue prosecution, decline prosecution, or refer the matter to other authorities. In fact, the prosecutor even has a wide variety of alternatives to charging the defendant criminally. For instance, if the defendant is already on probation or parole, a prosecutor could pursue the matter administratively as a probation violation (easier burden of proof), or let some other person or entity handle 
the matter in its entirety (via civil suits, parole hearings, mental hospitals, community agencies, or other law enforcement agencies with jurisdiction over the defendant). ${ }^{56}$

Although research concerning the charging decision is relatively sparse,${ }^{57}$ many have argued that the decision to prosecute is influenced by both legal and extralegal factors. For instance, probable cause must exist before a suspect can be charged with a crime. ${ }^{58}$ Secondly, the "strength of the case, the credibility of complainants and witnesses, the existence and admissibility of corroborating proof, and the nature and strength of the defense" also serve as significant legal constraints on the exercise of a prosecutor's discretion. ${ }^{59}$ However, many extralegal factors also have an influence on the prosecutor's charging decision, such as, but not limited to, the character of the organization involved, ${ }^{60}$ the defendant, ${ }^{61}$ the victim, ${ }^{62}$ the surrounding environment,${ }^{63}$ the individual prosecutor's stereotypical beliefs of what a jury would likely do with the case,${ }^{64}$ publicity and public opinion, ${ }^{65}$ and the need to reduce uncertainty about the outcome of the case. ${ }^{66}$ The primary factor influencing the decision to charge a person with a crime is the ability to secure a conviction (i.e., the defendant's convictability - what has been characterized as a prosecutor's "downstream orientation" regarding the processing of cases). ${ }^{67}$ Therefore, when making the decision to charge or not charge a physician with a crime, the prosecutor essentially asks: Could this physician be convicted in this community under the existing facts?

\section{White-collar and medical crime}

Research involving white-collar and medical crime helps distinguish between detection of a violation of law and the likelihood that health care professionals will be prosecuted. The terms "white-collar crime, medical crime, and occupational crime" are merely descriptive areas of the criminal justice literature; we do not infer that the conduct of the physicians featured in our scenarios is criminal in nature.

Although several definitions exist, white-collar crime may be best defined by what it is not - namely, it is "neither street crime nor conventional crime." ${ }^{68}$ White-collar crimes are generally crimes that are committed by professionals who enjoy relatively high social status. Within this broad area of literature lies the subcategory of medical crime, representing offenses committed by medical professionals within the scope of their employment (also known as occupational crime) ${ }^{69}$ As a subfield of white-collar crime, medical crime shares many of the same problems regarding detection, investigation, and prosecution associated with the broader white-collar crime category. ${ }^{70}$

For instance, white-collar crimes are not given the same priority as street crimes despite the fact that white-collar crime/occupational crime is far more costly in human and financial terms. ${ }^{71}$ There are a variety of reasons for this misplaced attention. First, unlike street crimes, white-collar crimes are usually not committed in public view and quite often go undetected by either the general public or the victim. ${ }^{72}$ Secondly, white-collar crimes are often complex and require specialized expertise in their detection, investigation, and successful prosecution. ${ }^{73}$

Moreover, due to the secretive nature of white-collar crime, it is also severely underreported in both frequency of occurrence and prosecution. Because prosecutors screen cases for further investigation and prosecution, the number of cases accepted for prosecution grossly underrepresents the frequency of occurrence. ${ }^{74}$ Even in the context of Medicare fraud, where enforcement personnel are specially trained to investigate offenses, investigators believe that the number of physicians detected represents merely the "tip of the iceberg" and those prosecuted tend to constitute only the most egregious cases. ${ }^{75}$

Proving intent also presents a special problem, particularly when the individual conduct stems from differences in "professional opinion" (e.g., the method of treatment). ${ }^{76}$ Moreover, the existence of civil remedies as an alternative to criminal prosecution is often considered, particularly in light of the high standard of proof that is required in a criminal proceeding. ${ }^{77}$ Consequently, what actually constitutes a criminal case could be processed only as a civil or administrative matter, keeping it out of the crime reporting loop.

\section{Prosecuting physicians}

Physicians have been prosecuted for a wide array of conduct related to their profession, ranging from violations of controlled substance laws to Medicare fraud. ${ }^{78}$ In fact, several commentators argue that the frequency of physician prosecutions is on the rise. ${ }^{79}$ This increase has been attributed to a variety of factors, one of which stems from the perception that the medical profession or state medical boards and regulatory agencies are incapable of adequate monitoring and control..$^{80}$ Other commentators argue that the general decline in our level of trust in social institutions, the emergence of managed care (where medicine is perceived more as a business than a profession), and the willingness of prosecutors to prosecute when they perceive that traditional control systems are weak are also factors at play. ${ }^{81}$

Albeit limited, some research has also been conducted on what factors may contribute to charging a physician with an offense. For instance, some researchers argue that the size of the community matters ("juries are often reluctant to convict doctors, particularly in small towns where they may have built up a grateful clientele"), ${ }^{82}$ or the nature of the defendant's occupation. ${ }^{83}$ Two recently published studies help inform the debate over the likelihood of being prosecuted, particularly for the aggressive treatment of pain at the end of life.

In 1994, Meisel, Jernigan, and Youngner (1999) ${ }^{84}$ examined the willingness of prosecutors to prosecute a physician for his or her care of dying patients in light of both their personal and professional opinions. Although this large-scale 
and interesting study suffered from a low rate of response, several of its findings were noteworthy. For instance, over the three less controversial scenarios presented to prosecutors, "no more than one fifth of the respondents would take measures that might lead to formal prosecution, such as an indictment." 85 Specifically, one of the scenarios involved the planned use of morphine to alleviate the pain "of a terminally ill, competent cancer patient." ${ }^{86}$ In the scenario's narrative, the health care professionals were depicted as being "concerned about possible criminal liability if the morphine [was] administered" and the patient died. ${ }^{87}$ The results indicated that 18.9 percent of the prosecutors would be willing to take formal action against the physician, 61 percent would not, and 20.1 percent were undecided. ${ }^{88}$

Four years later, researcher Ann Alpers reviewed published material in an effort to analyze "what actions have put physicians or nurses at risk for criminal investigation or prosecution in connection with their care of dying patients, particularly their management of pain." ${ }^{89}$ Professor Alpers found that there were

no systematic efforts by any state or local government to target health care providers or dying patients for routine investigation or review. The treatment of terminal pain is never investigated unless someone knowledgeable about the treatment informs either a hospital supervisor, an ethics committee, or a local prosecutor. ${ }^{90}$

Alpers found that environmental and defendant characteristics may have played a role in the decision to prosecute. For instance, excepting five physicians in Minnesota, "all of the cases [prosecuted or investigated] occurred in small towns or rural counties." ${ }^{91}$ Moreover,

Many of the health care providers [who were prosecuted or investigated] were outsiders - either newly arrived, members of racial or ethnic minorities, or living alternative lifestyles. ${ }^{92}$

Alpers ultimately concluded that the decision to investigate or prosecute health care providers was not motivated by "suspicious or overzealous prosecutors," but rather stemmed from "intercollegial discord and miscommunication or disagreements between providers and families." 93

\section{Purpose of OUR STUdY}

The purpose of this pilot study is to examine empirically whether the fear of criminal investigation and prosecution is based on a realistic assessment of risk and, further, to document what factors contribute to and predict the likelihood of prosecution in the context of providing pain relief through the use of prescription drugs.

\section{Methods}

\section{Population and selection of states}

Our population consisted of all chief prosecuting officials at the county level in the states of Connecticut, Maryland, Oregon, and Washington $(N=112)$. Although we were dealing with an exempt population (persons holding public office), we sought and received approval for studies involving human subjects from our university's institutional review board. Oregon and Washington were chosen because the issues of pain relief and physician-assisted suicide are highly salient in Oregon due to the state's legalization of the practice, and the neighboring state of Washington provided a means of comparison in light of its similarity in size and lack of a physician-assisted suicide statute. Connecticut was selected for three primary reasons. First, unlike the prosecutors/district attorneys in the western states, prosecutors in Connecticut (state's attorneys) are appointed to their posts for 8-year terms. Their jurisdiction is also not set at the county level, but rather extends over a judicial district. Second, the Donaghue Medical Research Foundation had recently funded research on the barriers to pain management in that state, and our research would add to this scholarship. ${ }^{94}$ And third, its location in the eastern part of the United States would provide contrast to the two western states. Although it was not within our budget or original plan, we also decided to include the state of Maryland in our study. As an eastern state, Maryland would not only add to the results of Connecticut, but the number of prosecutors in Maryland would increase the validity of our study by adding another twenty-four potential respondents. Moreover, although Maryland state's attorneys usually do not endorse studies, we found that the Maryland Attorney General's Office was very supportive of our research. Although the office had no control over the local prosecutors in that state, it became a valuable resource to our study, as did the several national and state prosecuting attorneys associations contacted during the course of our research.

\section{Instrument}

Building on prior scholarship in both the medicolegal and social science literatures, we constructed a self-administered, mailed questionnaire consistent with the Tailored-Design Method. ${ }^{95}$ The pre-tested questionnaire consisted of fortyfour items concerning the topics of pharmaceutical diversion, pain relief, physician-assisted suicide, euthanasia, and factors that would likely contribute to whether or not a physician would be charged with an offense. As did Meisel, Jernigan, and Youngner, ${ }^{96}$ we used scenarios involving patients and physicians, but we varied the approach somewhat by asking respondents to estimate the likelihood that they would take action on a scale from 0 percent to 100 percent. By allowing answers along a range of scores rather than the traditional yes-or-no dichotomy, we gained flexibility in response range 
and captured the intensity of each respondent's views. In light of our own methodological concerns, such as the ordering of the questions, we specifically designed the questions so that respondents would have to estimate the likelihood that they would take action or inaction on each particular scenario. The likelihood they would take no action can be implied from low scores on the range of 0 percent to 100 percent. We recognize that, in reality, cases presented to prosecutors have unique facts and that our scenarios are therefore somewhat artificial. However, scenarios remain a valuable tool in both research and education because each respondent gets the same scenario (stimulus), and both attorneys and physicians are accustomed to dealing with proposed scenarios during the course of their earlier training and later discussions with colleagues.

This article reports on the two scenarios in the survey instrument entailing the aggressive treatment of pain among terminally ill and chronic noncancer pain patients, and investigates questions related to addiction, pharmaceutical diversion, and the prosecution of physicians.

The first scenario in our study concerns the legitimate but aggressive treatment of chronic noncancer pain identified as a potential problem by a pharmacist (see Scenario 1). Pharmacists have a responsibility to ensure that controlled substances are dispensed for a legitimate medical purpose (although quantity, frequency, and amount of dispensing by themselves are insufficient indicia of inappropriate prescribing). Moreover, prosecutors often have to rely on informants to flag their cases since "the criminal justice system plays a passive role in policing physician behavior." ${ }^{97}$ Consequently, we were curious if prosecutors would recommend investigation of the physician (known to have a chilling effect on opioid dispensing), refer the matter to the Drug Enforcement Administration (DEA), or refer the matter to the state medical board in lieu of investigation or prosecution.

The second scenario involves the treatment of a terminally ill patient experiencing respiratory distress who, after morphine administration, goes into respiratory arrest and dies (see Scenario 2). Although the likelihood of respiratory arrest is negligible, ${ }^{98}$ and with proper titration, morphine "can be used safely and effectively," tial to "depress both the rate and depth of respiration" to the point of respiratory arrest. ${ }^{100}$ This second scenario illustrates the principle of double effect. ${ }^{101}$ The scenario is also analogous to the testimony of Dr. William Hunter, given before a congressional committee in support of the Pain Relief Promotion Act of 1999. ${ }^{102}$ Dr. Hunter described the basic facts of Scenario 2 as a daily occurrence in the United States. He stated that he would not fear prosecution under such circumstances. Therefore, it would be quite remarkable if our study revealed that several prosecutors would indeed take action against the physician featured in Scenario 2, either by referring the matter to the state medical board or through investigation and/or prosecution.

In addition to the two scenarios, our questionnaire also included a list of factors that our literature review indicated may be important to the decision to charge. We built on the previous work of several scholars, such as Benson et al., Benson and Cullen, Ayers and Frank, and Liederbach et al. ${ }^{103}$ To allow some means of comparison, portions of the survey made use of a format followed by several previous surveys of health care professionals, state regulators, and prosecutors on questions involving pharmaceutical diversion and addiction. ${ }^{104}$

\section{Implementation}

Consistent with self-administered survey protocol, we conducted three waves of mailings, beginning in November 2001 and ending in February 2002. Several noteworthy events occurred around the time of these mailings. First, the terrorist attacks on the United States on September 11, 2001, and the subsequent Anthrax letter incidents resulted in delays. Second, less than 2 months after these tragic events, U.S. Attorney General John Ashcroft reversed the ruling of former Attorney General Janet Reno that Oregon's use of controlled substances for physician-assisted suicide did not violate the federal Controlled Substances Act. U.S. Attorney General Ashcroft opined that any physician in Oregon who used con-

\section{SCEnARio 1}

A pharmacist, who has a corresponding responsibility to ensure that prescriptions for controlled substances are issued for a legitimate medical purpose, is concerned that a doctor who specializes in pain relief has been prescribing controlled substances in dosage amounts that often exceed what the average physician prescribes. Although the particular doctor prescribes both narcotic and nonnarcotic substances to his patients, one of his most frequently prescribed drugs are morphine tablets, a very potent and effective pain reliever. Morphine, however, has the potential for both abuse and diversion; abusers can either self-medicate beyond the dosage or frequency designated by the doctor, or they can resell the product on the street for a significant profit. The pharmacist also told the police that this particular doctor has prescribed pain medication to some of his patients for periods beyond 30 days (in fact, some of the doctor's patients have been receiving pain medication in excess of 6 months). Based on this information, the police suspect that the doctor is contributing to the drug problem by doling out too many prescriptions too frequently and at higher dosages than the average physician. The police seek your advice. 
SCEnARIO 2

On Monday morning a hospice doctor was summoned to the home of a 25 -year-old AIDS patient. The doctor specializes in hospice care and admits that he prescribes "controlled substances with the frequency that an infectious disease practitioner uses antibiotics." The doctor also admits that he prescribes controlled substances in his practice in doses that exceed "the standard doses utilized in drug trials mandated by the FDA to prove safety in selected populations." The doctor is often involved in cases in which the side-effects of medications may contribute to the deaths of his patients. Upon his arrival at the patient's home, family members told the doctor that the patient was having difficulty breathing. When the doctor entered the room he could hear that indeed the patient's breathing was both labored and moist (excess fluid existed in the patient's lungs). The patient was unconscious and his respiratory rate was 44 breaths per minute (the respiration rate for this particular patient should be about 20 breaths per minute). The doctor injected the patient with $40 \mathrm{mg}$ of Lasix (a medication which helps rid the body of salt and water). There was no effect. The doctor then injected the patient with $10 \mathrm{mg}$ of morphine and waited several minutes. There was no effect. The doctor then gave the patient $5 \mathrm{mg}$ of morphine, and again there was no effect. In what the doctor describes as an attempt to sedate the patient and ease the work of breathing, he gave the patient $5 \mathrm{mg}$ of Valium (which had no effect). The doctor then gave another $5 \mathrm{mg}$ of morphine, waited, saw no effect, and gave another $10 \mathrm{mg}$ of morphine. After a few minutes, the patient's respirations decreased to about 20 per minute. However, instead of stabilizing at 20, the patient's breathing rate continued to diminish, and several minutes later the patient stopped breathing and died.

trolled substances to hasten death, even if it was in compliance with Oregon state law, would risk revocation of their permit to prescribe controlled substances. ${ }^{105}$

\section{RESULTS}

\section{Respondent characteristics}

Our population consisted of 112 potential respondents, representing the total number of chief prosecuting officials in all four states (Connecticut: 13; Maryland: 24; Oregon: 36; and Washington: 39). See Table 1. During the course of our survey, two Oregon district attorneys in rural, one-person offices resigned (one of the surveys was returned to us with a note that there were no physicians in the county). We subsequently eliminated these two counties from our population and reduced our population size accordingly (from thirty-six to thirty-four in Oregon, and from 112 to 110 overall). Of the 110 questionnaires mailed, eighty-four were returned and useable, resulting in a total response rate of 76.36 percent. The overall response rate was excellent, but varied somewhat among the four states (Connecticut: 61.54 percent; Maryland: 70.83 percent; Oregon: 70.59 percent, and Washington: 89.74 percent).

All questionnaires were filled out either by the chief prosecuting officials themselves (79.8 percent), or their senior deputy (20.2 percent). The number of years that respondents were in their present position ranged from 1 to 28 years, with an average (mean) of 9.69 years. The majority of our respondents were elected to their position (72.6 percent), and although some of our respondents held either appointed or nonpartisan positions, most considered themselves Democrats (42.9 percent), with the remaining group identifying themselves as Republicans (34.5 percent), Independents (15.5 percent), or other (2.4 percent).
Determining the number of full-time prosecutors in an office, annual felony caseload, and the population served by the office is important when assessing the surrounding environment. As noted earlier, Ann Alpers found that the majority of published prosecutions of health care providers occurred in small towns or rural jurisdictions. ${ }^{106}$ Earlier research acknowledged the correlation between population and the number of prosecutors in an office. ${ }^{107}$ In establishing a reliable method for jurisdiction classification, we believed that the number of full-time prosecutors, the office's annual caseload, and the jurisdiction's population figures would serve as more useful proxies for statistical analysis than the traditional triad of rural, suburban, and urban, which are often inaccurate descriptions. These proxies made logical sense on their face, and we ultimately found that the three indicators were interrelated. For example, the correlation between the number of prosecutors and population was nearly perfect (Pearson's $r=0.949$ ), as was the correlation between annual felony caseload and population $(r=0.863)$; the correlation between annual felony caseload and the number of full-time prosecutors was also highly correlated $(r=0.905)$. All correlations were significant at the 0.01 level.

In this study, the number of full-time prosecutors in an office ranged from one to 250 . The average number of prosecutors in a jurisdiction was eighteen, the median eight, and the mode was two. The annual felony caseload among the offices in the four states ranged from a low of twenty to a high of 12,000 . The average (mean) annual felony caseload was 1,299 , and the median was 500 . Finally, according to the 2000 U.S. Census, the population of each of our jurisdictions ranged from a low of 1,934 to a high of $1,737,034$. Consistent with earlier research, ${ }^{108}$ forty-nine out of eightyfour of our responding jurisdictions (58 percent) could be classified as rural environments with populations of less than 100,000 . 


\section{Table 1. Respondent Characteristics.}

$\begin{array}{lcl}\text { States and Response Rates } & & \\ \text { Connecticut } & 8 / 13 & (61.54 \%) \\ \text { Maryland } & 17 / 24 & (70.83 \%) \\ \text { Oregon } & 24 / 34 & (70.59 \%)^{*} \\ \text { Washington } & 35 / 39 & (89.74 \%) \\ \text { Total Response Rate } & 84 / 110 & (76.36 \%)\end{array}$

Official Position of Respondents

$\begin{array}{lll}\text { Chief Prosecutors } & 67 & (79.8 \%) \\ \text { Senior Deputy Prosecutors } & 17 & (20.2 \%)\end{array}$

$\begin{array}{lc}\text { Number of Years in Present } & \text { Position } \\ \text { Range } & 1-28 \text { years } \\ \text { Mean } & 9.69 \text { years } \\ \text { Median } & 7.0 \text { years }\end{array}$

\section{Elected or Appointed}

$\begin{array}{lll}\text { Elected } & 61 & (72.6 \%) \\ \text { Appointed } & 23 & (27.4 \%)\end{array}$

$\begin{array}{lcc}\text { Party Affiliation** } & & \\ \text { Democrat } & 36 & (42.9 \%) \\ \text { Republican } & 29 & (34.5 \%) \\ \text { Independent } & 13 & (15.5 \%) \\ \text { Other } & 2 & (2.4 \%) \\ \text { Not Provided } & 4 & (4.8 \%)\end{array}$

Number of Prosecutors in Office

\begin{tabular}{lc|} 
Range & $1-250$ prosecutors \\
Mean & 18 \\
Median & 8 \\
Mode & 2 \\
& \\
Annual Felony Caseload & \\
Range & $20-12,000$ cases \\
Mean & 1,299 \\
Median & 500 \\
\multicolumn{3}{l}{ Population of Jurisdictions } \\
Range & \\
Mean & $1,934-1,737,034$ \\
Median & 171,802 \\
Number of jurisdictions & 75,328 \\
under 100,000 residents & $49(49 / 84=58.3 \%)$ \\
\hline
\end{tabular}

*Oregon has thirty-six counties. However, at the time of the survey, two district attorneys serving rural jurisdictions in one-person offices left their position.

**Self-identified, not all positions partisan.

\section{Knowledge about addiction}

Prosecutors were asked to express their opinion about the risk of addiction when a patient is prescribed narcotics for pain relief. See Table 2. The definition of addiction is often misunderstood even by clinicians. ${ }^{109}$ The question was tailored to our respondent population by asking: "In your opinion, what is the risk of addiction whenever a patient is prescribed narcotics for pain relief?" Respondents could answer by selecting one choice along a four-point scale: $0=$ No risk of addiction; 1 = Risk is low; $2=$ Risk is moderate; 3 = Risk is high. Respondents could also select "Don't know." Twelve prosecutors indicated that they did not know. Of those expressing an opinion, 22.2 percent responded that the risk of addiction was high; over twice as many viewed the risk of addiction as moderate (51.4 percent), and 26.4 percent saw the risk of addiction as being low. None of the respondents indicated that there was no risk of addiction.

\section{Questions concerning diversion}

Several questions concerning pharmaceutical diversion were asked. See Tables 3-5. As noted earlier, deceptive patients are far and above the most likely source of diverted pharmaceuticals; dated doctors (those who are out of touch or lax in prescribing behavior) are a distant second, followed by impaired and dishonest doctors. ${ }^{110}$ Respondents were asked to rate the level of blame for diversion among these parties by assigning a value between 1 and 4 . Those considered the least responsible for diversion would receive a score of 1 ; those most responsible would receive a score of 4 . Most prosecutors correctly believed that deceptive patients were the most responsible for diversion (the average/mean score for deceptive patients was 3.35, and both the median and mode were 4). See Table 3. Based on the mode scores for the remaining parties, impaired doctors arrived a distant second, with responsibility scores of 2.19 (mean) and 2.0 for both the median and mode. Dishonest doctors received an average (mean) score of 2.28 , and dated doctors received an average (mean) responsibility score of 2.20. Nine respondents indicated that they did not know who was least or most to blame for pharmaceutical diversion.

Respondents were also asked to comment on the diversion problem in their jurisdiction and state by selecting one choice along a four-point scale: $0=$ Diversion not a problem; 1 = Diversion is a minor problem; 2 = Diversion is a moderate problem; 3 = Diversion is a major problem. See Table 4. Respondents could also select "Don't know." Consistent with prior research concerning proximity and citizen perceptions of problems in their neighborhood versus their city, ${ }^{111}$ prosecutors viewed diversion as a bigger problem in their state than in their own jurisdiction. For example, when asked about the diversion problem in their own jurisdiction, 57.5 percent of those expressing an opinion viewed diversion as only a minor problem, 32.5 percent saw it as a 


\begin{tabular}{|lccc|}
\hline \multicolumn{4}{c|}{ Table 2. In Your Opinion, What Is the Risk of Addiction Whenever a Patient Is Prescribed } \\
Narcotics for Pain Relief? & Frequency & Valid Percent & Cumulative Percent \\
\hline & 19 & 26.4 & 26.4 \\
Risk is low & 37 & 51.4 & 77.8 \\
Risk is moderate & 16 & 22.2 & $\mathbf{1 0 0}$ \\
Risk is high & 12 & & \\
Don't know & $\mathbf{8 4}$ & $\mathbf{1 0 0}$ & \\
Total & &
\end{tabular}

\begin{tabular}{|c|c|c|c|c|}
\hline Category & Number of Responses & MODE & Mean & Median \\
\hline Dated doctors & 69 & 1 & 2.20 & 2.00 \\
\hline Dishonest doctors & 67 & 1 & 2.28 & 2.00 \\
\hline Impaired doctors & 67 & 2 & 2.19 & 2.00 \\
\hline Deceptive patients & 75 & 4 & 3.35 & 4.00 \\
\hline
\end{tabular}

moderate problem, and only 5 percent saw diversion as a major problem or not a problem at all. Only four respondents claimed not to know what the diversion problem was in their jurisdiction. However, when asked about the extent of the diversion problem in their state, most saw it as a bigger problem than in their own jurisdiction (38.5 percent saw it as a minor problem, 53.8 percent saw it as a moderate problem, and 7.7 percent saw diversion as a major problem in the state). Although nineteen respondents admitted to not knowing what the diversion problem was outside of their jurisdiction, none of them answered that diversion was "not a problem."

\section{Scenario 1 (Treatment of chronic pain)}

Scenario 1 concerned the treatment of chronic noncancer pain. It is now generally accepted that the dosage, frequency, and duration of opioid use alone do not constitute sufficient evidence to indicate inappropriate use. Therefore, we constructed a scenario that illustrated these principles to help determine if physicians' fear of investigation was warranted.

\section{Likelihood of recommending police investigation}

The survey indicated the presence of a broad spectrum of opinion. Of the eighty-three prosecutors responding, thirtyeight of them (45.8 percent) estimated the likelihood of recommending a police investigation to be 40 percent or less, whereas thirty-six of them (43.4 percent) estimated the likelihood at 60 percent or more. See Table 6 . However, the most common response (the mode) was 10 percent (19.3 percent of the prosecutors estimated the likelihood of recommending investigation at only 10 percent). The overall mean likelihood of recommending a police investigation was 48.8 percent. However, when examining the means of the states individually, a pattern emerged. The average likelihood of recommending a police investigation in Oregon was the lowest (34.3 percent likelihood). The average was about the same for Connecticut as it was for Washington (48.8 percent and 46.6 percent, respectively), but the average likelihood of recommending a police investigation was much higher in Maryland (72.9 percent average likelihood that the prosecutor, here a state's attorney, would recommend a police investigation). See Figure 1.

\section{Table 4. To What Extent Do You Think the Diversion of Drugs Is a Problem in Your Jurisdiction?}

\begin{tabular}{|lccc|} 
& Frequency & Valid Percent & Cumulative Percent \\
Diversion not a problem & 4 & 5.0 & 5.0 \\
Diversion is a minor problem & 46 & 57.5 & 62.5 \\
Diversion is a moderate problem & 26 & 32.5 & 95.0 \\
Diversion is a major problem & 4 & 5.0 & $\mathbf{1 0 0}$ \\
Don't know & 4 & & \\
Total & $\mathbf{8 4}$ & $\mathbf{1 0 0}$ & \\
\hline
\end{tabular}




\begin{tabular}{lccc|}
\hline Table 5. To What Extent Do You Think the Diversion of Drugs Is a Problem in Your State? \\
\hline & Frequency & Valid Percent & Cumulative Percent \\
Diversion is a minor problem & 25 & 38.5 & 38.5 \\
Diversion is a moderate problem & 35 & 53.8 & 92.3 \\
Diversion is a major problem & 5 & 7.7 & $\mathbf{1 0 0}$ \\
Don't know & 19 & & \\
Total & $\mathbf{8 4}$ & & \\
\hline
\end{tabular}

Likelihood of referring matter to the state medical board in lieu of investigation or prosecution

The prosecutors as a group were more likely to refer the matter to the state medical board than recommend a police investigation. See Table 7 . The survey results relating to the first scenario indicated that 52.4 percent of the respondents estimated the likelihood of referring the matter to the state medical board to be 60 percent or greater. The mean likelihood of referral was 57.0 percent. Individually, the western states indicated a slightly higher likelihood of referring the matter to the state medical board than the eastern states (Oregon: 62.9 percent; Washington: 57.1 percent; Maryland: 51.8 percent; and Connecticut: 50.0 percent). See Figure 2.

\section{Likelihood of DEA referral}

There was little risk that prosecutors would refer this particular matter to the DEA. See Table 8 . The majority of prosecutors (54.8 percent) placed the likelihood of DEA referral at 10 percent or less (35.7 percent of the prosecutors estimated a 0 percent likelihood). Remarkably, only 16.7

$\begin{array}{|cccc|}\text { Table 6. } & \text { Scenario 1: What Is the LikeliHood } \\ & \text { That You Would Recommend A Police } \\ & \text { Investigation OF This Doctor? }\end{array}$

percent of the respondents indicated that the likelihood of referring the matter to the DEA was 60 percent or greater. The mean score was 24.1 percent (likelihood of referral). When examining the likelihood of referring the matter by each state individually, Connecticut had the highest score with an average (mean) of 32.5 percent compared to Maryland at 26.5 percent, Oregon at 27.1 percent, and Washington at 20.0 percent.

\section{Comments by prosecutors attributable to the above scenario and diversion topics}

In addition to the quantitative data, we also reviewed the comments made by prosecutors that were attributable to the preceding questions. For instance, five of the respondents indicated to us that instead of referring the matter to the state medical board in lieu of investigation or prosecution, they would retain jurisdiction and recommend a concurrent investigation of the physician. ${ }^{112}$ Respondents also commented on the extent of diversion in their jurisdiction and the competency of the medical board in their state. ${ }^{113}$

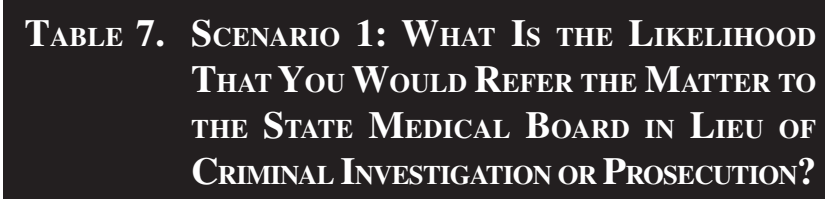

\begin{tabular}{|cccc|}
\hline & Frequency & Percent & $\begin{array}{c}\text { Cumulative } \\
\text { PerceNT }\end{array}$ \\
$0 \%$ & 5 & 6.0 & 6.0 \\
$10 \%$ & 6 & 7.1 & 13.1 \\
$20 \%$ & 9 & 10.7 & 23.8 \\
$30 \%$ & 7 & 8.3 & 32.1 \\
$40 \%$ & 3 & 3.6 & 35.7 \\
$50 \%$ & 10 & 11.9 & 47.6 \\
$60 \%$ & 4 & 4.8 & 52.4 \\
$70 \%$ & 5 & 6.0 & 58.3 \\
$80 \%$ & 12 & 14.3 & 72.6 \\
$90 \%$ & 13 & 15.5 & 88.1 \\
$100 \%$ & 10 & 11.9 & $\mathbf{1 0 0}$ \\
Total & $\mathbf{8 4}$ & $\mathbf{1 0 0}$ & \\
\hline
\end{tabular}


Figure 1. Scenario 1: Likelihood of Recommending a Police Investigation.

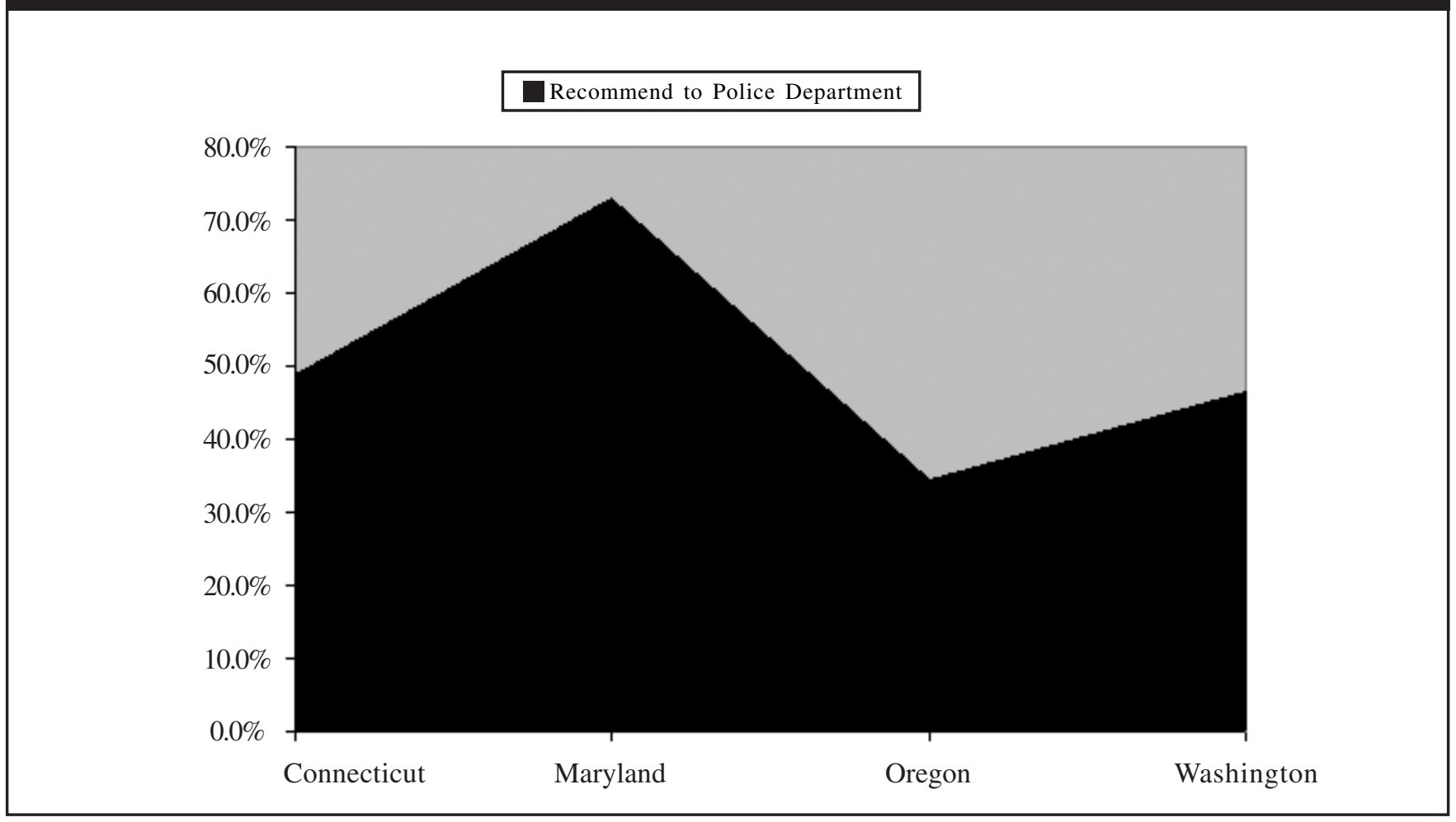

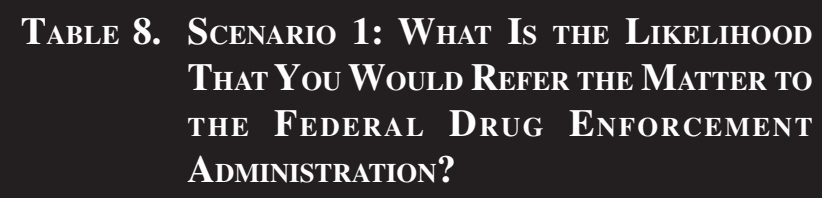

\begin{tabular}{|cccc|}
\hline & Frequency & PerceNT & $\begin{array}{c}\text { Cumulative } \\
\text { PerceNT }\end{array}$ \\
$0 \%$ & 30 & 35.7 & 35.7 \\
$10 \%$ & 16 & 19.0 & 54.8 \\
$20 \%$ & 10 & 11.9 & 66.7 \\
$30 \%$ & 6 & 7.1 & 73.8 \\
$40 \%$ & 2 & 2.4 & 76.2 \\
$50 \%$ & 6 & 7.1 & 83.3 \\
$60 \%$ & 1 & 1.2 & 84.5 \\
$70 \%$ & 4 & 4.8 & 89.3 \\
$80 \%$ & 3 & 3.6 & 92.9 \\
$90 \%$ & 4 & 4.8 & 97.6 \\
$100 \%$ & 2 & 2.4 & $\mathbf{1 0 0}$ \\
Total & $\mathbf{8 4}$ & $\mathbf{1 0 0}$ & \\
\hline
\end{tabular}

\section{Scenario 2 (Pain and the dying patient)}

Scenario 2, based upon the testimony of Dr. William Hunter, a hospice physician, concerned the commonly accepted use of morphine in the treatment of terminally ill patients and the concurrent risk of respiratory depression.
Likelihood of referring matter to the state medical board in lieu of investigation or prosecution

The survey results indicated that exactly half of the respondents estimated the likelihood of referring the matter to the state medical board in lieu of investigation or prosecution at 60 percent or greater. See Table 9.

The average score was 56.5 percent (likelihood of state medical board referral). However, as with the first scenario, we found that opinions differed widely by state. For example, whereas Connecticut prosecutors (state's attorneys) estimated the likelihood of referring the matter to the state medical board to be 38.8 percent, Oregon prosecutors (district attorneys) estimated the likelihood at 49.2 percent, Washington at 56.7 percent, and Maryland at 75.9 percent. Maryland prosecutors (state's attorneys) differed considerably between the two scenarios (they recommended investigation in the first, yet were content to refer the matter to the state medical board in lieu of investigation in the second). See Figure 2.

\section{Whether a prosecutable offense was committed}

Prosecutors were also asked whether they believed an offense had been committed in Scenario 2. See Table 10. Sixteen prosecutors (19 percent) answered yes, 26.2 percent responded no, and 52.4 percent said "Don't know." The sixteen prosecutors who indicated that an offense had been committed were also asked to specify what offense (or offenses) oc- 


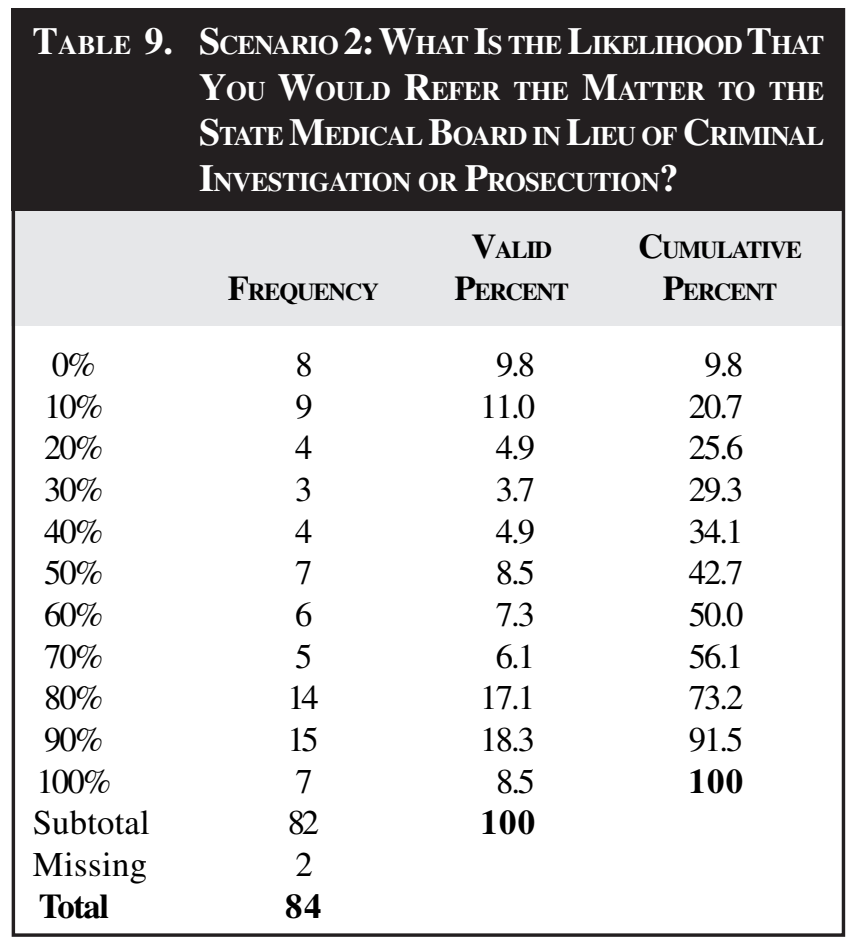

curred. ${ }^{114}$ Responses included homicide/murder (10), manslaughter (6), endangerment (1), and a violation of controlled substances laws (1). See Table 10.

Recognizing that there is a distinction between classifying something as an offense and prosecuting it, we also asked respondents to estimate the likelihood that they would actually prosecute. Most who considered it an offense would have prosecuted. Specifically, of the sixteen respondents who answered yes, eight of them estimated the risk of prosecution at 60 percent or more. The average (mean) likelihood of prosecution was 55.0 percent (as was the median).

As before, several of our respondents provided us with some noteworthy comments regarding the scenario, including a need for a more fact-intensive inquiry. ${ }^{115}$ Additionally, the prosecutors indicated deference to experts in these areas and the difficult standard of proof. ${ }^{116}$

\section{Factors influencing the decision to prosecute physicians}

Three question categories addressed the prosecution of physicians directly. The first question concerned the effectiveness of the medical profession in policing its members. See Table 11. Responses ranged from a low of 1 (not effective) to a high of 7 (very effective). ${ }^{117}$ Earlier research indicated that the risk of prosecution of physicians may be related to a prosecutor's perception of the ability of the medical profession to monitor its own. ${ }^{118}$ Our second set of questions concerned the number of physicians prosecuted in their jurisdiction over the past 12 months (see Table 12), and the third set focused on what factors would play a significant role in the decision to charge a physician with a crime (see Table 13).

\section{Ability of profession to police its own}

Most prosecutors did not believe that the medical profession was particularly effective in policing its own members. See Table 11. Of those offering an opinion, 52.7 percent assigned an evaluation score of 3 or less (whereas only 20.3 percent gave a score of 5 or better), and the mean effectiveness score was 3.28. Roughly one-in-ten of the prosecutors indicated that they did not know how effective the medical profession was in policing its own members.

\section{Number of physicians prosecuted}

The majority of prosecutors reported that no physicians in their jurisdictions were prosecuted over the past 12 months for offenses relating to prescription drugs (88.1 percent of the prosecutors reported zero; and 10.7 percent reported prosecuting one to two physicians). See Table 12 . Only one jurisdiction of the eighty-four that responded reported prosecuting three or more physicians for offenses relating to prescription drugs (likely an aberration for that jurisdiction).

\section{Important factors in the decision to charge a physician with an offense}

Our final question concentrated on what specific factors would contribute to the decision to charge a physician with an offense relating to prescription drugs. See Table 13. Earlier research by Benson and Cullen; Jesilow, Pontell, and Geis;

\begin{tabular}{|c|c|c|c|}
\hline \multicolumn{4}{|c|}{$\begin{array}{l}\text { Table 10. Scenario 2: Based on the Scenario } \\
\text { Do You Believe That an Offense(s) } \\
\text { Has Been Committed? }\end{array}$} \\
\hline Response & FREQUENCY & Percent & $\begin{array}{l}\text { Cumulative } \\
\text { Percent }\end{array}$ \\
\hline Yes & 16 & 19.0 & 19.0 \\
\hline No & 22 & 26.2 & 45.2 \\
\hline Don't know & 44 & 52.4 & 97.6 \\
\hline Missing & 2 & 2.4 & 100 \\
\hline Total & 84 & 100 & \\
\hline \multicolumn{4}{|c|}{ If Yes, What Would the Offense(s) Be? } \\
\hline \multicolumn{2}{|c|}{ LIKELY OFFENSE } & \multicolumn{2}{|l|}{ FREQUENCY } \\
\hline \multicolumn{2}{|c|}{ Homicide/Murder } & 10 & \\
\hline \multicolumn{2}{|c|}{ Manslaughter } & 6 & \\
\hline \multicolumn{2}{|c|}{ Endangerment } & 1 & \\
\hline \multicolumn{2}{|c|}{ Drug violation } & 1 & \\
\hline
\end{tabular}


Figure 2. Scenarios 1 and 2: Average Likelihood of Referral to Medical Board.

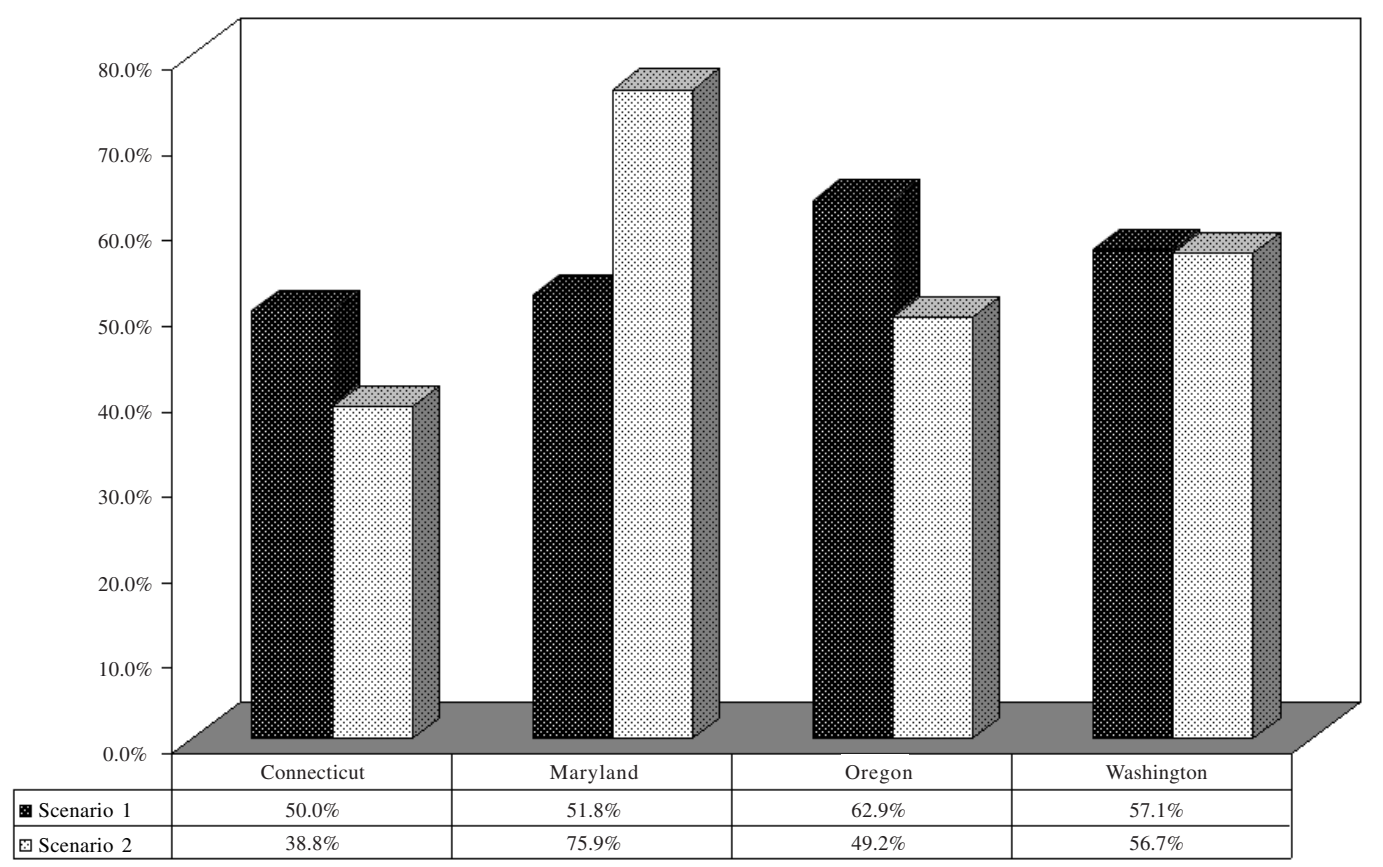

Benson et al.; and Ayers and Frank ${ }^{119}$ greatly informed this area of our own research. We adapted their approaches to the prosecution of physicians and compiled a list of sixteen potentially influential factors on the decision to charge. Respondents were asked to rate the significance of each factor by assigning a value on a Likert scale of 0 to 3 , where $0=$ Not important; 1 = Somewhat important; 2 = Important; and $3=$ Very important.

Prosecutors believed that several factors were "very important" to the charging decision, such as: (1) whether the medical board had investigated and handled the matter appropriately (41 percent of the respondents); (2) whether the board investigated but failed to take appropriate action (36.1 percent); and (3) whether the doctor emphasized his own financial interests over patient care (56.6 percent).

Respondents also found several factors to be "important" to the charging decision: (1) whether the state medical board is currently investigating the case (36.1 percent); (2) whether federal criminal or regulatory action has already been filed against the defendant (39.8 percent) (a total of 78.4 percent of the respondents thought this was either an important or very important factor); (3) whether the police actively seek prosecution of the defendant (47 percent); (4) whether the case is extremely complex (38.3 percent); (5) what the victim or family's preference regarding prosecution is (54.9 percent); (6) whether the doctor's conduct was moti- vated by compassion (43.9 percent); and (7) whether the prosecution would likely deter future misconduct by doctors (55.6 percent).

Surprisingly, prosecutors regarded the following to be only "somewhat important" factors in the decision to charge: (1) the amount of media attention on the case (51.2 percent) (92.6 percent of the respondents thought that the amount of media attention on the case was only either somewhat important or not important); (2) the lack of public support for prosecuting the defendant (51.2 percent); and (3) the fact that the doctor was not a pain specialist (43.8 percent) (e.g., general practitioner).

Finally, respondents regarded three of the remaining factors to be "not important" at all: (1) whether a civil suit had already been filed against the defendant (57.8 percent); (2) whether there was a scarcity of physicians in the area $(84.3$ percent); and (3) whether the decision to charge would adversely affect their professional career (63.4 percent).

\section{Predicting a Prosecutor's Decision to Take Action}

We found several variables to be strong predictors of how our respondents assessed the likelihood of taking action against doctors portrayed in the two scenarios. The following section reports on those factors found to be statistically significant predictors of whether the prosecutor would either recom- 
mend a police investigation of the physician in Scenario 1, or refer the matter to the state medical board in Scenario 1 or 2. We note from the outset that human behavior is extremely complex and variable. It is best to think in terms of tendencies and probabilities instead of absolute certainties when predicting behavior for little is certain in our world (except, of course, death and taxes). Moreover, in light of this journal's interdisciplinary readership, we present a straightforward, uncomplicated statistical analysis, focusing only on those variables that demonstrated significant predictive potential. Subsequent theory-driven statistical modeling and additional qualitative research are indicated to fully explore the data collected in this survey.

\section{Analysis}

We began our analysis by converting our dependent variable — the likelihood of recommending or referring — from a percentage scale to a yes-or-no dichotomy (this was for methodological reasons since the statistical approach taken here, T-tests, requires a dichotomous dependent variable). Responses from a 0 percent to 40 percent likelihood were re-coded as no (would not recommend/refer); those indicating a likelihood of 60 percent or above were re-coded as yes (would recommend/refer). Because the middle response (50 percent) was at the halfway point and did not show a tendency either way in our dichotomy, it was omitted from the computation (and consequently reduced the likelihood of bias were we to attribute the middle response to either a yes or a no). Relying on the use of T-tests to compare means, ${ }^{120}$ we identified several factors that were statistically associated with the respondents' answers in our survey. ${ }^{121}$ These variables were then reported along with their statistical

\section{Table 11. To What Degree Do You Believe That the Medical Profession Is Effective in Policing Its Own Members?}

\begin{tabular}{|lccc|}
$\begin{array}{l}\text { Effectiveness } \\
\text { Score (1-7) }\end{array}$ & Frequency & $\begin{array}{c}\text { Valid } \\
\text { PerCeNT }\end{array}$ & $\begin{array}{c}\text { Cumulative } \\
\text { PerceNT }\end{array}$ \\
1 (Not effective) & 11 & 14.9 & 14.9 \\
2 & 13 & 17.6 & 32.4 \\
3 & 15 & 20.3 & 52.7 \\
4 (Uncertain) & 20 & 27.0 & 79.7 \\
5 & 10 & 13.5 & 93.2 \\
6 & 4 & 5.4 & 98.6 \\
7 (Very effective) & 1 & 1.4 & $\mathbf{1 0 0}$ \\
Subtotal & 74 & $\mathbf{1 0 0}$ & \\
Don't know & 9 & & \\
Missing & 1 & & \\
Total & $\mathbf{8 4}$ & & \\
& & & \\
Average score: 3.28 & & & \\
\hline
\end{tabular}

\begin{tabular}{|c|c|c|c|}
\hline \multirow[t]{2}{*}{ TABLE 12.} & \multicolumn{3}{|c|}{$\begin{array}{l}\text { Within the Past } 12 \text { Months, How } \\
\text { Many Doctors Were Prosecuted in } \\
\text { Your Jurisdiction for Offenses } \\
\text { Related to the Prescribing of Drugs? }\end{array}$} \\
\hline & 0 & $1-2$ & $3-6$ \\
\hline Connecticut & 5 & 2 & 1 \\
\hline Maryland & 16 & 1 & 0 \\
\hline Oregon & 22 & 2 & 0 \\
\hline Washington & 31 & 4 & 0 \\
\hline Total & $74(88.1 \%)$ & $9(10.7 \%)$ & $1(1.2 \%)$ \\
\hline
\end{tabular}

significance ( $p$-values) in Table 14. Statistical models were then constructed with these variables, and we relied on discriminant analysis to achieve a multivariate assessment of how well each one of the variables, taken in combination with each other, helped us predict whether a prosecutor would recommend a police investigation in Scenario 1 or refer the matter to the state medical board in either Scenario 1 or 2 . Those results are listed in Table 15.

\section{Significant predictors}

The ability to predict our respondents' decision to recommend a police investigation of the physician or refer the matter to the state medical board varied across the states and between hypothetical scenarios. Specifically, in Scenario 1 we found nine factors (variables) that exercised a statistically significant influence on whether the prosecutor would recommend a police investigation of the physician. See Table 14. In fact, one of the strongest predictors of whether the prosecutor would recommend such an investigation was related to his or her opinion concerning the risk of addiction when narcotics are used to treat pain. See Table 15. The predictor's standardized coefficient was 0.614 , indicating a tendency to recommend an investigation. Moreover, as our tables indicate, it also mattered if the prosecutor hailed from Maryland or Oregon, the likelihood he or she would refer the matter to the medical board in Scenario 2, whether the prosecutor was a Republican, and how important he or she considered the following factors in the decision to charge: the amount of media attention, the lack of public support for prosecuting the doctor, and whether the doctor's conduct was motivated by compassion. Based on these several predictors, the multivariate statistical model for survey findings in Scenario 1 was able to correctly predict the decision to recommend a police investigation 69 percent of the time (i.e., the model correctly predicted that the prosecutor would have estimated the likelihood of investigation at 60 percent to 100 percent in 69 percent of the cases). See Table 15.

The models concerning the likelihood of referring the matter to the state medical board featured fewer predictors, but they were more efficacious. Specifically, regarding the 
Table 13. How Significant Woủzó the Following Factors Be in Your Decision to Charge a Doctor with an Offense Relating to the Prescribing of Drugs?

The Board is currently investigating the case

The Board investigated and handled the matter appropriately

The Board investigated the matter and failed to take appropriate action

$\begin{array}{cccc}\text { Not } & \text { SOMEWHAT } & & \text { VERY } \\ \text { IMPORTANT } & \text { IMPORTANT } & \text { IMPORTANT } & \text { IMPORTANT } \\ \mathbf{0} & \mathbf{1} & \mathbf{2} & \mathbf{3}\end{array}$

\section{B. Involvement of Other Agencies or Jurisdictions}

Civil suit has already been filed against defendant

Federal criminal or regulatory action has already been filed against defendant

Police actively seek prosecution of defendant

$\begin{array}{rrrr}10.8 \% & 30.1 \% & \mathbf{3 6 . 1 \%} & 22.9 \% \\ 9.6 \% & 14.5 \% & 34.9 \% & \mathbf{4 1 \%} \\ 13.3 \% & 20.5 \% & 30.1 \% & \mathbf{3 6 . 1 \%}\end{array}$

\begin{tabular}{rrrr}
$\mathbf{5 7 . 8 \%}$ & $30.1 \%$ & \multicolumn{1}{c}{$8.4 \%$} & $3.6 \%$ \\
& & & \\
$4.8 \%$ & $16.9 \%$ & $\mathbf{3 9 . 8 \%}$ & $38.6 \%$ \\
$3.6 \%$ & $36.1 \%$ & $\mathbf{4 7 \%}$ & $13.3 \%$
\end{tabular}

\section{Case and Community Factors}

Case is extremely complex

Victim or family's preference regarding prosecution

Scarcity of physicians in area

Evidence that doctor emphasized his own financial interests over patient care

Amount of media attention on the case

Lack of public support for prosecuting defendant

Possible adverse consequences to your career

Doctor's conduct was motivated by compassion

Prosecution would likely deter future conduct by doctors

Doctor is not a pain specialist (e.g., general practitioner)

$\begin{array}{cccc}22.2 \% & 29.6 \% & \mathbf{3 8 . 3 \%} & 9.9 \% \\ 2.4 \% & 26.8 \% & \mathbf{5 4 . 9 \%} & 15.9 \% \\ \mathbf{8 4 . 3 \%} & 7.2 \% & 4.8 \% & 3.6 \% \\ & & & \\ 3.6 \% & 3.6 \% & 36.1 \% & \mathbf{5 6 . 6 \%} \\ 45.7 \% & \mathbf{4 6 . 9 \%} & 6.2 \% & 1.2 \% \\ 25.6 \% & \mathbf{5 1 . 2 \%} & 18.3 \% & 4.9 \% \\ \mathbf{6 3 . 4 \%} & 28.0 \% & 8.5 \% & 0 \% \\ 2.4 \% & 30.5 \% & \mathbf{4 3 . 9 \%} & 23.2 \% \\ 3.7 \% & 22.2 \% & \mathbf{5 5 . 6 \%} & 18.5 \% \\ 28.7 \% & \mathbf{4 3 . 8 \%} & 23.8 \% & 3.8 \%\end{array}$

likelihood of referring the matter to the state medical board in Scenario 1, five factors (variables) were found to be statistically significant and the model correctly classified cases 74.2 percent of the time $(p<0.01)$. In the case of Scenario 2 , nine factors (variables) were found to be statistically significant predictors and the model correctly classified (predicted) whether the prosecutor would have referred the matter to the medical board 78.2 percent of the time ( $p<0.01$ ). All findings, including the relative strength and direction of each variable, have been reported in Table 15. Although the application of both linear and logistic regression statistical analyses to these survey data is indicated, the more elementary statistical analysis presented here serves well to highlight some of the key factors that influence a prosecutor's decision regarding investigation or case referral for physicians suspected of abusing their opioid prescribing privileges.

\section{DISCUSSION}

As social scientists, rather than advocates, we must strive continually to remain impartial and above the fray, particu- larly when the topic of research involves highly charged issues. ${ }^{122}$ During the review process, some colleagues suggested that our findings could be spun in different directions by the media or by health care professionals who seek to shift the blame for their undertreatment of pain. We do not wish to discourage this independent interpretation; we would hope only that those interpreting our results do so in an openminded manner. With this hope in mind, we turn now to a discussion of our results.

\section{Are physicians' fear of investigation or prosecution justified?}

One of the central questions that we sought to address in our study was whether medical practitioners' pervasive fear of being investigated or prosecuted for the aggressive treatment of pain is a realistic fear. Our findings indicate that in some circumstances an investigation stemming from the aggressive treatment of pain is indeed likely. However, this conclusion must be understood within its proper context. For instance, although the likelihood of investigation in Sce- 


\section{Table 14. T-Test Results.}

Predicting Likelihood of Recommending a Police Investigation in Scenario 1

\section{Scenario 1: Variables Having Significant Effects}

Refer to medical board in Scenario 2

State of Maryland

Opinion concerning risk of addiction

Whether lack of public support was a factor (see Table 13)

State of Oregon

Deceptive patients as a source of diversion

Whether doctor motivated by compassion

Identified self as a Republican

Whether amount of media attention was important (see Table 13)

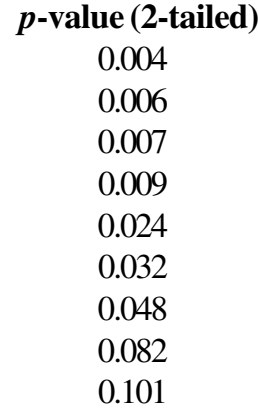

0.006

0.007

0.009

0.024

0.032

0.048

0.082

0.101

Predicting Referral of Cases to State Medical Board (Scenarios 1 and 2)

Scenario 1: Variables Having Significant Effects

Prosecutor requested summary of our findings

Number of part-time prosecutors in office

Likelihood would refer matter to DEA in Scenario 1

State of Oregon

Opinion regarding risk of addiction when narcotics are used to treat pain

\author{
p-value (2-tailed) \\ 0.001 \\ 0.018 \\ 0.037 \\ 0.066 \\ 0.090
}

\section{Scenario 2: Variables Having Significant Effects}

Prosecutor requested summary of our findings

Likelihood would recommend police to investigate in Scenario 1

State of Maryland

State of Oregon

Identified self as a Republican

Doctor emphasized financial interest over patient

Dated doctors source of diversion

Identified self as an Independent

Lack of public support for prosecuting defendant (see Table 13)

$\boldsymbol{p}$-value (2-tailed)
0.001
0.004
0.013
0.048
0.074
0.081
0.087
0.089
0.101

nario 1 is greater in Maryland than it is in Oregon, there was a great deal of variation among prosecutors within each state. Moreover, although Maryland prosecutors were more likely to recommend an investigation in Scenario 1, they were also more likely to refer the matter to the state medical board in lieu of investigation in Scenario 2. Any increased likelihood of investigation is likely the result of insufficient knowledge regarding the legitimate use of opioids in the aggressive treatment of pain and the limited experience of prosecutors when dealing with such matters.

\section{Scenario 1}

Our first scenario involved the aggressive treatment of chronic pain. As we noted earlier, the dosage and frequency of opioid prescribing are insufficient grounds to trigger an investigation. Additionally, the facts in the scenario are not indicative of inappropriate treatment protocols. Nevertheless, almost half of our respondents indicated that the likelihood of rec- ommending an investigation of the physician was 60 percent or greater. However, when we separate the results, there are distinct differences between the states. For example, the average risk of investigation among three of the states did not exceed 48.8 percent (Connecticut), and Oregon had the lowest average risk score of 34.3 percent. In contrast, the average risk of investigation in Scenario 1 in Maryland was 72.9 percent -29.67 percent higher than the average of the three other states combined (see Figure 1). This mean difference between the states was statistically significant both here and in our earlier section on predicting a prosecutor's decision to take action (where both Maryland and Oregon were statistically significant predictors of whether the prosecutor would recommend a police investigation of the physician). See Tables 14 and 15.

Regarding Scenario 1, we also asked prosecutors to determine the likelihood of referring the matter to the state medical board in lieu of investigation or prosecution. Although a few of the prosecutors remarked that they would 
retain jurisdiction over the matter and conduct an investigation in addition to making the referral to the state medical board, prosecutors were generally content to refer the entire matter to the state medical board. However, there were striking differences across the individual states here as well. Whereas Maryland was more likely (and Oregon least likely) to recommend a police investigation, Oregon was more likely (and Connecticut least likely) to refer the matter in its entirety to the state medical board (see Figure 2). More specifically, 62.9 percent of Oregon district attorneys would refer, compared to an average of 52.96 percent for the other three states combined. In fact, in comparison to the other three states, Oregon was found to be a statistically significant predictor of whether the matter would be referred to the state medical board.

Finally, although we found a broad range of viewpoints regarding both investigation and referral to the state medical board, there was consensus among local prosecutors that referral to the DEA was extremely unlikely.

We were surprised by our results in Scenario 1, particularly as they related to the likelihood of recommending a police investigation of the physician. Although most prosecutors indicated a low to moderate risk of investigation, some prosecutors (particularly those in Maryland) indicated a high likelihood. It is unclear what factors account for the high scores. Even though the police are often obligated to follow up once they receive a complaint, the eventual police investigation may amount to nothing more than a telephone call. Moreover, one of the more plausible explanations stems from the realization that opinions held by prosecutors are not all that different from those held by health care providers, physicians, and pharmacists concerning the regulation of opioids. As mentioned above, 26.4 percent of Texas physicians agreed with the statement: "Prescribing narcotics for patients with chronic pain is likely to trigger a drug enforcement agency investigation"; and 47.7 percent agreed that "If I follow the same prescribing practices as other doctors in my field, I will not be investigated by a regulatory agency." 123 In another survey, only 16.6 percent of New Jersey pharmacists saw the practice of prescribing opioids for more than several months as lawful and generally acceptable, and $\mathbf{4 7 . 2}$ percent thought that, albeit lawful, such prescribing was generally not acceptable and should be discouraged. ${ }^{124}$ Although Joranson and Gilson's survey of Wisconsin pharmacists indicated an overall greater level of legal and medical acceptance of extended opioid prescriptions, a "significant minority" believed that the use of some opioids described in the study "should be discouraged or investigated." 125 Finally, in a survey of medical board members, Gilson and Joranson ultimately concluded that "most medical board members continued to view prolonged prescribing of opioid analgesics for chronic non-cancer pain as inappropriate medical practice and something to be discouraged or even investigated." 126
Concerning the risk of addiction, the views held by prosecutors are also similar to those held by many physicians. For instance, although the risk of addiction when narcotics are used to treat pain is generally low, 20 percent of prosecutors estimated the risk of addiction as "high" and 43 percent estimated the risk as "moderate." These same misperceptions were shared by many physicians and medical board members (see, e.g., the study that found that 27.9 percent of Texas physicians agreed with the statement: "Any patient who is given narcotics for pain relief is at a significant risk for addiction"; ${ }^{127}$ as well as the studies involving state medical board members who "overestimated the incidence of addiction"128). Notwithstanding these similarities in viewpoints, some of the opinions held by prosecutors did differ from the medical establishment, particularly when considering the scope and extent of the pharmaceutical diversion problem.

Most prosecutors correctly noted that the primary source of pharmaceutical diversion was deceptive patients, not physicians. Moreover, when prosecutors were asked about the extent of the diversion problem in their jurisdiction and state, most saw diversion as a bigger problem elsewhere. Their perception that pharmaceutical diversion was not a big problem in their own jurisdiction was buttressed by the fact that 88 percent of the respondents reported that no physicians had been prosecuted in their jurisdiction during the past 12 months for offenses stemming from the prescribing of drugs (11 percent reported prosecuting one to two physicians, and only 1 percent reported between three and six physicians). The opinions held by prosecutors concerning the extent of the diversion problem are in contrast to studies involving pharmacists and medical board members. For example, the Wisconsin survey of pharmacists found that 46 percent "viewed diversion and abuse of prescription opioid analgesics as a problem in their community" (55 percent of them saw diversion as "a moderate problem"). ${ }^{129}$ The survey of New Jersey pharmacists found that 36 percent believed that both diversion and addiction were "serious problems," 130 and the Gilson and Joranson study of medical board members found that "most respondents in [1991 and 1997] considered diversion to be a minor to moderate problem."131

Prosecutors appear to recognize that deceptive patients are the primary source of diversion, few have prosecuted physicians for offenses relating to prescription drugs, and they generally do not consider pharmaceutical diversion to be a significant problem in their jurisdiction. Therefore, it is not likely that prosecutors would devote much attention to identifying or prosecuting doctors suspected of diversion unless the investigation arises from a complaint by a medical practitioner or family member related to a case. ${ }^{132}$ Admittedly, prosecutors deal with such matters on an infrequent basis, and therefore it is logical that they would recommend a police investigation in Scenario 1 when even health care professionals lack sufficient knowledge about what constitutes legitimate opioid use. 


\section{Table 15. Discriminant Analysis Results.}

Predicting Likelihood of Recommending a Police Investigation in Scenario 1

\section{Scenario 1 (Chronic Pain)}

Model Fit: Chi-square: 16.940 (degrees of freedom =9)
Statistical Significance: $p<0.05$ (two-tailed)
Model Elements \& Standardized Canonical Discriminant Function Coefficients

Refer to Medical Board in Scenario 2

State of Maryland

0.508

0.412

0.614

$-0.319$

$-0.356$

$-0.113$

$-0.047$

$-0.076$

$-0.296$

Republican

Amount of media attention

Model Efficacy: $\mathbf{6 9 . 0 \%}$ of cases correctly classified with this model

Predicting Referral of Cases to State Medical Board (Scenarios 1 and 2)

Scenario 1 (Chronic Pain)

Model Fit: Chi-square: $19.679($ degrees of freedom $=5$ )

Statistical Significance: $p<0.01$ (two-tailed)

Model Elements \& Standardized Canonical Discriminant Function Coefficients

Prosecutor requested summary of our findings $\quad 0.595$

Number of part-time prosecutors $\quad-0.496$

Likelihood would refer matter to DEA in Scenario $1 \quad 0.546$

$\begin{array}{lr}\text { State of Oregon } & 0.306\end{array}$

Risk of addiction when narcotics are used $\quad-0.345$

Model Efficacy: $\mathbf{7 4 . 2 \%}$ of cases correctly classified with this model

Scenario 2 (Terminally Ill Patient)

Model Fit: Chi-square: 27.129 (degrees of freedom =9) Statistical Significance: $p<0.01$ (two-tailed)

Model Elements \& Standardized Canonical Discriminant Function Coefficients

Prosecutor requested summary of our findings

Likelihood would recommend investigation in Scenario 1

0.569

State of Maryland

0.016

State of Oregon

$-0.148$

Republican

0.180

Doctor emphasized financial interest over patient care

$-0.071$

Dated doctors as source of diversion

0.452

Independent

$-0.136$

Lack of public support for prosecuting defendant

$-0.055$

Model Efficacy: $78.2 \%$ of cases correctly classified with this model

\section{Scenario 2}

Whereas the first scenario concerned the aggressive treatment of chronic noncancer pain and physicians' fear that they could be prosecuted for pharmaceutical diversion, the second scenario addressed physicians' fear of prosecution for physician-assisted suicide or euthanasia should a terminally ill patient expire immediately following aggressive opioid administration. We found that although the risk of prosecution was indeed quite low, the likelihood that the matter would be referred to the state medical board varied significantly across states.

Most prosecutors did not know if an offense had been committed (51.4 percent); almost a third indicated that no offense had occurred, and less than 20 percent believed that 
an offense had taken place. In terms of referring the matter to the medical board in lieu of prosecution, over 50 percent of the respondents estimated the likelihood of referring the matter at 70 percent or greater. However, as noted previously, there were several significant differences among the states. For example, whereas prosecutors in Maryland were more likely to recommend a police investigation in Scenario 1 (72.9 percent likelihood), Maryland prosecutors were also the most likely to refer the matter in its entirety to the state medical board in Scenario 2. Specifically, for Maryland prosecutors (state's attorneys) the average likelihood of referring the matter to the state medical board was 75.9 percent as compared to 56.7 percent in Washington, 49.2 percent in Oregon, and 38.8 percent in Connecticut. Although a few of the prosecutors in our study remarked that they would not refer the matter in lieu of investigation or prosecution, ${ }^{133}$ it was clear that prosecutors were not particularly interested in handling the matter themselves.

\section{Predicting prosecutorial action using both descriptive and inferential statistics}

The final part of our survey addressed prosecutions of physicians. Earlier research found that the prosecution of physicians for end-of-life treatment was relatively rare, and most prosecutions occurred in "small towns or rural counties." 134 With the exception of Connecticut, criminal prosecution of physicians for offenses related to the prescribing of drugs during the past 12 months was virtually nonexistent. The few physicians who were prosecuted for prescribing practices in our sample practiced or resided in larger, more urbanized areas. Specifically, in the ten offices that reported prosecuting a physician during the past 12 months, the number of prosecutors in each of these offices were as follows: 1, 5, 12, 17, 23, $26,30,70,86$, and 250. Because the number of full-time prosecutors in an office is highly correlated with the jurisdiction's population (Pearson's $r=0.949, p<0.01$ ), population and the number of full-time prosecutors are useful proxies for categorizing the type of jurisdiction/ environment. When we recall that the median number of prosecutors in an office across all four states was eight, and jurisdictions over 100,000 citizens had at least twelve prosecutors in an office, it is apparent that most of the prosecutions of physicians came from large jurisdictions in populous areas. Although we found a moderate statistical correlation between the population size and the number of physicians prosecuted (Pearson's $r=0.359, p<0.01$ ), further research and formal modeling are necessary before any firm conclusions can be drawn in this regard.

Surprisingly, among the many factors offered, the scarcity of physicians in the area was not an important factor in the charging decision for almost all of the prosecutors surveyed. See Table 13. The score on this contextual environmental variable was in contrast to what has been ar- gued in the past concerning doctors ${ }^{135}$ and corporations (particularly, the impact of corporate prosecutions on the local economy). ${ }^{136}$ Contrary to our expectations, the lack of public support, the amount of media attention, and the possible adverse consequences to their career were reported to have little bearing on the decision to charge (rated as either not important or somewhat important). While most prosecutors are elected officials who need to be at least somewhat responsive to the local citizenry, the consistent downgrading of what factors were and were not important over four states is too strong to dismiss as bias related to the strategic decisionmaking of elected prosecutors.

Of the factors that were rated by prosecutors as important in the charging decision, deterrence of other physicians was expected, particularly in light of scarce resources. However, in the context of prescription opioids for the treatment of pain, such a policy could lead to overreaction in the medical community, which already perceives an unrealistically high threat of regulatory scrutiny. ${ }^{137}$ We were also not surprised by the importance given to whether a doctor emphasized his own financial interest over patient care in the charging decision, as well as whether the doctor's actions were motivated by compassion. On the other hand, we were surprised by the fact that 43.8 percent of the prosecutors considered whether the doctor was a pain specialist to be "somewhat important" in the decision to charge, and another 23.8 percent considered it to be "important." Any physician who is a DEA registrant may prescribe controlled substances for pain so long as it is for a legitimate medical reason in the usual course of his or her medical practice.

Aside from the numbers generated by the survey, some prosecutors commented that prosecutions involving doctors were complex and, absent outrageous circumstances, it was unproductive to prosecute them. One prosecutor even commented that the courts should probably keep out of the area entirely. In fact, a majority of prosecutors indicated that the complexity of a case was either somewhat important or important in the decision to charge. If the courts do stay out of this area, the alternative forum would likely be the state medical boards. In fact, two of the three most important factors upon which the prosecutors reportedly relied in the decision to charge a physician were (1) whether the state medical board had investigated and handled the matter appropriately (41 percent), and (2) whether the board had failed to take appropriate action (36.1 percent). (The third most important factor was whether the physician emphasized his own financial interests over patient care.)

Arguably, many prosecutors would be more than happy to let one centralized agency - here the state medical board - handle the matter (or at least be given an opportunity to do so). However, as our findings and the literature would suggest, this result is unlikely because most prosecutors tend to hold a rather dim view of the ability of the medical profession to police its own, and research has demonstrated that 
medical boards may be lacking the requisite knowledge about pain relief. ${ }^{138}$

Nevertheless, the involvement of, and appropriate handling of these matters by, state medical boards is an opportunity for these boards to assume a leadership role in improving the standard of care in pain relief and reducing the likelihood of police investigation in proper pain management. They could become the one source that prosecutors look to for guidance. In fact, one prosecutor even emailed us and remarked:

I would like to have the results of your survey. I'm also interested in other ways you can help our office. I guess it bothers me that we operate unilaterally and get all our outside information from the Feds. Let me know how we can help each other.

Being able to defer to the state medical board is not only sound from an informational and practical sense, it makes good political sense. Prosecutors have limited resources and must resolve problems with the wisest possible expenditure of those resources. When prosecutors can pass matters off to a competent regulatory entity, caseloads are reduced, thus saving prosecutorial resources for other areas.

\section{STUDY LIMITATIONS}

All research designs have weaknesses and potential for error. Although some of our case scenarios were based on actual events and all respondents received the same scenarios, real cases have their own unique problems and characteristics. The opinions provided by the respondents only accurately reflected their position at the time. ${ }^{139}$ Moreover, as a pilot study we limited our examination to four states, and the possibility exists that the opinions of these prosecutors do not reflect those of similarly situated individuals in the remaining forty-six states.

\section{CONCLUSION}

The purpose of our study was to determine whether physicians' fear of criminal investigation or prosecution stemming from the prescription of opioids in the treatment of pain was realistic and, if so, what factors could predict a likely investigation. Although earlier well done research indicated that the risk was low, these few studies either relied on published data or primarily concerned the withdrawal or withholding of medical care. ${ }^{140}$

Our survey questionnaire was designed to achieve five goals: (1) to solicit a high rate of response; (2) to set forth meaningful and engaging scenarios; (3) to present a number of questions designed to permit the testing of hypothesized predictors of prosecutorial action against doctors who are aggressive in the treatment of pain; (4) to provide variation in responses; and (5) to show whether any of the hypothesized factors or variables do predict prosecutorial action. All five goals were accomplished.

In reality, each case presented to a prosecutor has a unique set of facts and applicable law. However, each one of our respondents received the same questionnaire and not all responded in the same way. Although our pilot study was limited to four states, our literature review and findings have yielded insight concerning the detection and prosecution of offenses involving physicians and the prescribing of controlled substances. While the likelihood of detection is rare, ${ }^{141}$ in the event that the conduct is discovered, the likelihood of investigation or referral to the state medical board depends considerably on which scenario and state are involved. As Figures 1 and 2 demonstrate, there was a great deal of variation (particularly when examining Oregon, a state where public policy on pain relief is highly salient). Moreover, we found several case factors that many prosecutors thought to be either very important or not important at all in their decision to charge a physician with a crime. Several variables, if known in advance, could actually predict whether the prosecutor would refer the matter to the state medical board or recommend a police investigation.

Our research can also serve as an assessment and educational tool for the legal, regulatory, and medical communities. For instance, we found that many of our respondents held views similar to those held by pharmacists, drug regulators, and physicians concerning drug addiction and the diversion of pharmaceuticals. But unlike pharmacists, drug regulators, and physicians who are in the business of health care, prosecutors do not think about the dispensing of prescription drugs on a frequent basis. Consistent with the conclusions of Ann Alpers, we also found that a prosecutor's decision to investigate, refer, or prosecute is not motivated by overzealousness, ${ }^{142}$ but most likely stems from a lack of knowledge concerning appropriate prescribing practices and opioid use. In fact, many of our respondents shared their own personal stories involving pain experienced by loved ones, and not only praised our research efforts but wanted to know whom they should consult in the future should similar scenarios arise. Several state and national prosecutor associations encouraged our research and expressed an interest in both our findings as well as in contributing to future studies of these issues.

In conclusion, while physicians' fear of prosecution or investigation is a barrier to pain relief in our society, as the social science literature and our results indicate, both the likelihood and frequency of either are extremely low. True, some doctors have abused their prescribing authority and have been prosecuted, but oftentimes the situations were patently illegal, such as the selling of prescriptions for cash or sex. ${ }^{143}$ Overall, prosecutions surrounding the prescription of opioids are rare. When confronted with the scenarios in 
this survey, many prosecutors were found to suffer from the same gaps in knowledge held by health care professionals and their regulators. A significant opportunity exists for state medical boards to take a leadership role in the proper treatment of pain and become a reliable resource to both the legal and medical communities. Instead of enacting more statutes, efforts should be directed toward the adoption of informed "guidelines or policy statements" by medical boards regarding the treatment of pain and the legitimate use of opioids. ${ }^{144}$ Balancing the need to treat patients who are suffering from pain against the need to prevent the incidence of opioid abuse remains a challenge. ${ }^{145}$ And while there are no simple solutions, sensitizing the legal, regulatory, and medical communities about the impact of their decisions on the treatment of pain is a step in the right direction.

\section{ACKNOWLEDGMENTS}

In addition to thanking the American Society of Law, Medicine $\&$ Ethics and the Mayday Fund for their funding and support, we are also grateful for the assistance provided by Tom McBride, J.D. (Washington Association of Prosecuting Attorneys); Aaron Gilson, Ph.D. (University of Wisconsin); Jack Schwartz, J.D. (Maryland Attorney General's Office); Winsor Schmidt, J.D., LL.M., Ruth Self, and Michael Gaffney, J.D. (Washington State University); Carolyn Norris (Oregon District Attorneys Association); Jan Jernigan, Ph.D., and Alan Meisel, J.D. (University of Pittsburgh); Stuart Youngner, M.D. (Case Western Reserve University); Michael Benson, Ph.D. (University of Cincinnati); Ann Alpers, J.D. (University of California, San Francisco); David Brushwood, R.Ph., J.D. (University of Florida); Newman Flanagan and Elaine Nugent (National District Attorneys Association, and American Prosecutors Research Institute); Sandra H. Johnson, J.D., LL.M. (Saint Louis University School of Law), as well as the many prosecutors, district attorneys, and state's attorneys who participated in our study and shared both their opinions and personal experiences.

\section{REFERENCES}

1. S.H. Johnson, "Disciplinary Actions and Pain Relief: Analysis of the Pain Relief Act," Journal of Law, Medicine \& Ethics, 24, no. 4 (1996): 319-27, at 319; S.H. Johnson, "Introduction: Legal and Regulatory Issues in Pain Management," Journal of Law, Medicine \& Ethics, 26, no. 4 (1998): 265-66, at 265; A. Alpers, "Criminal Act or Palliative Care? Prosecutions Involving the Care of the Dying," Journal of Law, Medicine \& Ethics, 26, no. 4 (1998): 308-31, at 308, 310; D.E. Hoffmann, "Pain Management and Palliative Care in the Era of Managed Care: Issues for Health Insurers," Journal of Law, Medicine \& Ethics, 26, no. 4 (1998): 267-89, at 267; T.E. Quill et al., "The Debate over Physician-Assisted Suicide: Empirical Data and Convergent Views," Annals of Internal Medicine, 128, no. 7 (1998): 552-58, at 55253; D.Y. Brockopp et al., "Barriers to Change: A Pain Management Project," International Journal of Nursing Studies, 35 (1998): 226 32; A.M. Gilson and D.E. Joranson, "Controlled Substances and
Pain Management: Changes in Knowledge and Attitudes of State Medical Regulators," Journal of Pain and Symptom Management, 21, no. 3 (2001): 227-37, at 227.

2. See Johnson, "Disciplinary Actions and Pain Relief: Analysis of the Pain Relief Act," supra note 1, at 319; D.E. Joranson and A.M. Gilson, "Improving Pain Management Through Policy Making and Education for Medical Regulators," Journal of Law, Medicine \&́ Ethics, 24, no. 4 (1996): 344-47, at 344; C.S. Hill, Jr., "The Negative Influence of Licensing and Disciplinary Boards and Drug Enforcement Agencies on Pain Treatment with Opioid Analgesics," Journal of Pharmacentical Care in Pain \& Symptom Control, 1, no. 1 (1993): 43-62, at 44; S. Tolle, "Family Reports of Pain in Dying Hospitalized Patients: A Structured Telephone Survey," Western Journal of Medicine, 172 (2000): 374-77, at 374; R. Shapiro, "Health Care Providers' Liability Exposure for Inappropriate Pain Management," Journal of Law, Medicine \& Ethics, 24, no. 4 (1996): 360-64, at 360; C.M. Ostrom, "Doctors Leery of U.S. Crackdown on Pain Drugs," The Seattle Times, January 29,2002 , at A1, A7.

3. R.K. Portenoy, "Opioid Therapy for Chronic Nonmalignant Pain: A Review of the Critical Issues," Journal of Pain and Symptom Management, 11, no. 4 (1996): 203-17, at 208; Shapiro, supra note 2, at 363; K.M. Foley, "The Relationship of Pain and Symptom Management to Patient Requests for Physician-Assisted Suicide," Journal of Pain and Symptom Management, no. 5 (1991): 289-97, at 291; S.M. Weinstein et al., "Physicians' Attitudes Toward Pain and the Use of Opioid Analgesics: Results of a Survey from the Texas Cancer Pain Initiative," Southern Medical Journal, 93, no. 5 (2000): 479-87; Hill, Jr., supra note 2; Brockopp et al., supra note 1.

4. D.E. Joranson and A.M. Gilson, "Controlled Substances, Medical Practice, and the Law," in H. Schwartz, ed., Psychiatric Practice Under Fire: The Influence of Government, the Media and Special Interests on Somatic Therapies (Washington, D.C.: American Psychiatric Press, 1994): 173-94; B.D. Greenwald and E.J. Narcessian, "Opioids for Managing Patients with Chronic Pain: Community Pharmacists' Perspectives and Concerns," Journal of Pain and Symptom Management, 17, no. 5 (1999): 369-75.

5. Portenoy, supra note 3, at 204; K.L. Sees and H.W. Clark, "Opioid Use in the Treatment of Chronic Pain: Assessment of Addiction," Journal of Pain and Symptom Management, 8, no. 5 (1993): 257-64, at 258; P.S. Whitecar, A.P. Jonas, and M.E. Clasen, "Managing Pain in the Dying Patient," American Family Physician, 61, no. 3 (2000): 755-64, at 761; Weinstein et al., supra note 3; Greenwald and Narcessian, supra note 4.

6. Joranson and Gilson, supra note 4, at 181.

7. Johnson, "Introduction: Legal and Regulatory Issues in Pain Management," supra note 1, at 265; D. Weissman, "Doctors, Opioids, and the Law: The Effect of Controlled Substances Regulations on Cancer Pain Management," Seminars in Oncology, 20, no. 1, suppl. A (1993): 53-58, at 55; Hill, Jr., supra note 2; Portenoy, supra note 3; Gilson and Joranson, supra note 1; D.E. Joranson and A.M. Gilson, "Pharmacists' Knowledge of and Attitudes Toward Opioid Pain Medications in Relation to Federal and State Policies," Journal of the American Pharmaceutical Association, 41, no. 2 (2001): 213-20; Weinstein et al., supra note 3; See Federation of State Medical Boards, Model Guidelines for the Use of Controlled Substances for the Treatment of Pain (adopted May 2, 1998), available at <http://www.medsch. wisc.edu/painpolicy/domestic/model.htm $>$ [hereinafter cited as FSMB Guidelines].

8. Joranson and Gilson, supra note 7, at 217; D.E. Joranson and Gilson, supra note 4, at 176.

9. Controlled Substances Act (1970), 21 U.S.C. $\mathbb{S} 801$ et seq.; R.R. Abood and D.B. Brushwood, Pharmacy Practice and the 
Law (Gaithersburg, Maryland: Aspen, 2001): at 192; Greenwald and Narcessian, supra note 4, at 374; D. Behr, "Prescription Drug Control Under the Federal CSA: A Web of Administrative, Civil, and Criminal Law Controls," Washington University Journal of Urban and Contemporary Law, 45 (1994): 41-119; FSMB Guidelines, supra note 7.

10. Gilson and Joranson, supra note 1; Joranson and Gilson, supra note 7; Greenwald and Narcessian, supra note 4; Weinstein et al., supra note 3 .

11. Johnson, "Disciplinary Actions and Pain Relief: Analysis of the Pain Relief Act," supra note 1, at 320, 326; C. Hyman, "Pain Management and Disciplinary Action: How Medical Boards Can Remove Barriers to Effective Treatment," Journal of Law, Medicine \& Ethics, 24, no. 4 (1996): 338-43, at 338; Joranson and Gilson, supra note 2, at 344; Shapiro, supra note 2, at 363; Hill, Jr., supra note 2, at 43-44; T.S. Jost, "Public Financing of Pain Management: Leaky Umbrellas and Ragged Safety Nets," Journal of Law, Medicine \& Ethics, 26, no. 4 (1998): 290-307, at 291; Portenoy, supra note 3; Alpers, supra note 1; Hoffmann, supra note 1; H. McIntosh, "Regulatory Barriers Take Some Blame for Pain Undertreatment," Journal of the National Cancer Institute, 83, no. 17 (1991): 1202-04; H. McIntosh, "How Physicians Handle Drug Investigations," Journal of the National Cancer Institute, 83, no. 18 (1991): 1282-84; R. Nowak, "Cops and Doctors: Drug Busts Hamper Pain Therapy," The Journal of NIH Research, 4 (1992): 27-28; Weinstein et al., supra note 3; Ostrom, supra note 2, at A1, A7.

12. Foley, supra note 3 , at 291; Hyman, supra note 11, at 338; Portenoy, supra note 3; Nowak, supra note 11; Brockopp et al., supra note 1.

13. Portenoy, supra note 3, at 204; Sees and Clark, supra note 5, at 258; Whitecar, Jonas, and Clasen, supra note 5, at 761; Weinstein et al., supra note 3; Greenwald and Narcessian, supra note 4.

14. Foley, supra note 3; Portenoy, supra note 3; Nowak, supra note 11; Hyman, supra note 11, at 338.

15. Weinstein et al., supra note 3 , at 481 .

16. Hill, Jr., supra note 2, at 45, 48.

17. A.M. Martino, "In Search of a New Ethic for Treating Patients with Chronic Pain: What Can Medical Boards Do?," Journal of Law, Medicine \& Ethics, 26, no. 4 (1998): 332-49, at 332.

18. B.B. Wilford et al., "An Overview of Prescription Drug Misuse and Abuse: Defining the Problem and Seeking Solutions," Journal of Law, Medicine \& Ethics, 22, no. 3 (1994): 197-203, at 199.

19. Wilford et al., supra note 18.

20. See W. Vilensky, R.A. Steer, and C.V. Weikel, "Background Characteristics of Judicious and Injudicious Prescribers in New Jersey," Journal of Forensic Sciences, 32, no. 1 (1987): 201-07 (found that 12 percent of injudicious prescribers were impaired).

21. Wilford et al., supra note 18; P.D. Jesilow, H.N. Pontell, and G. Geis, "Medical Criminals: Physicians and White-Collar Offenses," Justice Quarterly, 2 (1985): 149-65, at 155-56. See also Behr, supra note 9.

22. M.F. Conlan, "U.S. Congress May Try to Kill Oregon's Assisted-Suicide Law," Drug Topics, 143, no. 19 (October 4, 1999): 85-86, at 86; D. Orentlicher and A. Caplan, "The Pain Relief Promotion Act of 1999: A Serious Threat to Palliative Care," JAMA, 283, no. 2 (2000): 255-58, at 255-56; R. Shapiro, "Liability Issues in the Management of Pain," Journal of Pain and Symptom Management, 9, no. 3 (1994): 146-52, at 149; S.J. Ziegler and N.P. Lovrich, Jr., Prohibiting Physician-Assisted Suicide at the Expense of Pain Relief (September 2001), Pain and the Law Website, at <http://www.painandthelaw.org/mayday/ ziegler_lovrich_100301.php>; Ostrom, supra note 2. Although several people have used the terms interchangeably, euthanasia and physician-assisted suicide are actually two distinct practices and can be distinguished on the basis of patient control. Specifically, in physician-assisted suicide, the physician provides the means or instructions on how to hasten the patient's death, but it is the patient who must actually cause the consumption of the substance. In contrast, euthanasia ("mercy-killing") involves the administration of the substance by the physician (e.g., a lethal injection). D. Humphry and M. Clement, Freedom to Die: People, Politics, and the Right to Die Movement (New York: St. Martin's Griffin, 2000): at 287; N. Clark, The Politics of Physician-Assisted Suicide (New York: Garland Publishing, 1997): at 7, 10; R. Steinbrook, "Physician-Assisted Suicide in Oregon - An Uncertain Future," N. Engl. J. Med., 346, no. 6 (2002): 460-64, at 460.

23. J. Hallenbeck, "Terminal Sedation for Intractable Distress, "Western Journal of Medicine, 171, no. 4, (1999): 222-23, at 222; N.I. Cherny and R.K. Portenoy, "Sedation in the Management of Refractory Symptoms: Guidelines for Evaluation and Treatment," Journal of Palliative Care, 10, no. 2 (1994): 31-38; J. Hardy, "Sedation in Terminally Ill Patients, The Lancet, 356 (2000): 1866-67; A.J. Billings and S.D. Block, "Slow Euthanasia," Journal of Palliative Care, 12, no. 4 (1996): 21-30; N. Cantor, "Twenty-Five Years After Quinlan: A Review of the Jurisprudence of Death and Dying," Journal of Law, Medicine \& Ethics, 29, no. 2 (2001): 182-96; A. Alpers and B. Lo, "The Supreme Court Addresses Physician-Assisted Suicide. Can Its Rulings Improve Palliative Care?," Archives of Family Medicine, 8 (1999): 200-05.

24. Quill et al., supra note 1; Billings and Block, supra note 23; Cherny and Portenoy, supra note 23; Hallenbeck, supra note 23.

25. Cantor, supra note 23, at 187; Hallenbeck, supra note 23; T.E. Quill, B. Lo, and D.W. Brock, "Palliative Options of Last Resort: A Comparison of Voluntarily Stopping Eating and Drinking, Terminal Sedation, Physician-Assisted Suicide, and Voluntary Active Euthanasia," JAMA, 278, no. 23 (1997): 2099-104.

26. S. Fohr, "The Double Effect of Pain Medication: Separating Myth from Reality," Journal of Palliative Medicine, 1, no. 4 (1998): 315-28; A. Meisel, J.C. Jernigan, and S.J. Youngner, "Prosecutors and End-of-Life Decision Making," Archives of Internal Medicine, 159, no. 10 (1999): 1089-95.

27. Fohr, supra note 26, at 318-21; T.E. Quill, "Principle of Double Effect and End-of-Life Pain Management: Additional Myths and a Limited Role," Journal of Palliative Medicine, 1, no. 4 (1998): 333-36; Weinstein et al., supra note 3.

28. Fohr, supra note 26, at 316.

29. Fohr, supra note 26; Quill et al., supra note 1; Whitecar, Jonas, and Clasen, supra note 5.

30. Cantor, supra note 23, at 186.

31. See also Alpers and Lo, supra note 23; Meisel, Jernigan, and Youngner, supra note 26; D. Orentlicher, "The Supreme Court and Physician-Assisted Suicide: Rejecting Assisted Suicide but Embracing Euthanasia," N. Engl. J. Med., 337, no. 17 (1997): 1236-39, at 1236-37.

32. See generally A. Meisel, L. Snyder, and T. Quill, "Seven Legal Barriers to End-of-Life Care: Myths, Realities, and Grains of Truth," JAMA, 284, no. 19 (2000): 2495-501; Cantor, supra note 23

33. Steinbrook, supra note 22, at 463; L. Gostin, "Drawing a Line Between Killing and Letting Die: The Law, and Law Reform, on Medically Assisted Dying," Journal of Law, Medicine \& Ethics, 21, no. 1 (1993): 94-101, at 94; Orentlicher and Caplan, supra note 22

34. N. Cantor and G. Thomas, III, "Pain Relief, Acceleration 
of Death, and Criminal Law," Kennedy Institute of Ethics Journal, 6, no. 2 (1996): 107-28.

35. Orentlicher, supra note 31 . See also Billings and Block, supra note 23; Alpers and Lo, supra note 23.

36. Orentlicher and Caplan, supra note 22, at 256; Cantor, supra note 23; Cantor and Thomas, III, supra note 34; Alpers and Lo, supra note 23.

37. Lethal Drug Abuse Prevention Act, H.R. 4006, 105th Congress, 2d session (1998); Pain Relief Promotion Act (PRPA), H.R. 2260, 106th Congress (1999); Conlan, supra note 22, at 86; Orentlicher and Caplan, supra note 22; C. Baron, "Assisted Dying," Trial, 35, no. 7 (1999): 44-50. See also Ziegler and Lovrich, supra note 22; Steinbrook, supra note 22 (voicing concern that an intent to comfort terminal patients with the administration of opioids could be viewed by law enforcement as intent to hasten death).

38. Concerns over determining physicians' intent were raised by the Hospice Patients Alliance, which at one time encouraged people to report physicians to the Drug Enforcement Administration if a terminally ill patient died and prescription drugs were involved. See Hospice Patients Alliance, When Narcotics Are Misused in Order to Kill a Patient You Can Report the Crime to the U.S. Drug Enforcement Administration, at <http://www.hospice patients.org/usdoj-dea-ofclist.html > (last visited October 4, 2000).

39. Alpers, supra note 1 , at 309. Pamela Bucy notes that it "is unfortunate that the only mechanism readily available to study prosecutions of health care providers is through reported cases. This is inadequate for two reasons. First, courts are reporting fewer and fewer of their opinions.... Second, significant cases are often settled. These two deficiencies in the sample make it difficult to detect trends, especially in an area changing as rapidly as health care." P. Bucy, "The Poor Fit of Traditional Evidentiary Doctrine and Sophisticated Crime: An Empirical Analysis of Health Care Fraud Prosecutions," Fordham Law Review, 63 (1994): 383-528, at 386 n.6.

40. Alpers, supra note 1.

41. Meisel, Jernigan, and Youngner, supra note 26.

42. See, e.g., M.L. Benson and F.T. Cullen, Combating Corporate Crime: Local Prosecutors at Work (Boston: Northeastern University Press, 1998); M.L. Benson et al., "District Attorneys and Corporate Crime: Surveying the Prosecutorial Gatekeepers," Criminology, 26, no. 3 (1988): 505-18; M.L. Benson, F.T. Cullen, and G. Geis, "Local Prosecutors and Corporate Crime," Crime and Delinquency, 36, no. 3 (1990): 356-72; Jesilow, Pontell, and Geis , supra note 21; K.A. Ayers, Jr., and J. Frank, "Deciding to Prosecute White-Collar Crime: A National Survey of State Attorneys General," Justice Quarterly, 4, no. 3 (1987): 425-39.

43. Although the knowledge and opinions held by U.S. Attorneys are important as well, particularly since they work so closely with the Drug Enforcement Administration and have federal jurisdiction over conduct occurring in Veterans Administration (VA) hospitals, empirical research necessarily proceeds in steps. Consequently, in light of resource and time constraints, coupled with the realization that there are ten times more local prosecuting officials than appointed U.S. Attorneys, we narrowed our focus in this instant study to local prosecutors.

44. J.E. Jacoby, "The Charging Policies of Prosecutors," in W.F. McDonald, ed., The Prosecutor (Beverly Hills: Sage Publications, 1979): 75-95, at 76-77; J.E. Jacoby, The American Prosecutor: A Search for Identity (Lexington, Massachusetts: Lexington Books, 1980): at 195; C.W. Thomas and W.A. Fitch, "Prosecutorial Decision Making," American Criminal Law Review, 13, no. 3 (1976): 507-59, at 509; G.F. Cole, Politics and the Administration of Justice (Beverly Hills: Sage Publications, 1973).

45. Alpers, supra note 1 , at 308.
46. Jacoby, The American Prosecutor: A Search for Identity, supra note 44, at xix.

47. Id. at $x v$; Jacoby, "The Charging Policies of Prosecutors," supra note 44, at 75. The chief prosecuting attorneys in our study carry different titles: prosecuting attorney (Washington), district attorney (Oregon), and state's attorney (Connecticut and Maryland).

48. Cole, supra note 44, at 113-14.

49. Cole, supra note 44, at 112, 150; Jacoby, "The Charging Policies of Prosecutors," supra note 44, at 75.

50. F.W. Miller, Prosecution: The Decision to Charge a Suspect with a Crime, Report of the American Bar Foundation's Survey of the Administration of Criminal Justice in the United States (Boston: Little, Brown and Company, 1969): at 295; G.F. Cole, "The Decision to Prosecute," Law and Society Review, 4, no. 3 (1970): 331-43.

51. Jacoby, The American Prosecutor: A Search for Identity, supra note 44 , at 47.

52. Jacoby, "The Charging Policies of Prosecutors," supra note 44 , at 78 .

53. S.J. Cox, "Prosecutorial Discretion: An Overview." American Criminal Law Review, 13, no. 3 (1976): 383-434; Jacoby, The American Prosecutor: A Search for Identity, supra note 44; Miller, supra note 50; Thomas and Fitch, supra note 44.

54. R. Jackson, "The Federal Prosecutor," Journal of the American Judicature Society, 24 (1940): 18-20, at 18.

55. C. Spohn, D. Beichner, and E. Davis-Frenzel, "Prosecutorial Justifications for Sexual Assault Case Rejection: Guarding the Gateway to Justice," Social Problems, 48, no. 2 (2001): 206-35; Jacoby, The American Prosecutor: A Search for Identity, supra note 44.

56. M.R. Gottfredson and D.M. Gottfredson, Decision Making in Criminal Justice: Toward the Rational Exercise of Discretion, 2nd ed. (New York: Plenum Press, 1988): at 113-14. See also R. Teslik, Prosecutorial Discretion - the Decision to Charge: An Annotated Bibliography (Washington, D.C.: U.S. Department of Justice, Law Enforcement Assistance Administration, National Institute of Law Enforcement and Criminal Justice, 1975); J. Kaplan, "The Prosecutorial Discretion - A Comment." University of Northwestern Law Review, 60, no. 2 (1965): 174-93; Jacoby, The American Prosecutor: A Search for Identity, supra note 44; Miller, supra note 50; R.S. Frase, "The Decision to File Federal Criminal Charges: A Quantitative Study of Prosecutorial Discretion," University of Chicago Law Review, 47 (1980): 246-330; Thomas and Fitch, supra note 44; Cox, supra note 53.

57. C.A. Albonetti, "Prosecutorial Discretion: The Effects of Uncertainty," Law and Society Review, 21, no. 2 (1987): 291313, at 291; J. Eisenstein, "Unsettled Territory: An Overview of Research on The Legal Process," Law \& Courts (newsletter of the Law and Courts Section of the American Political Science Association), 11, no. 1 (2000): 1-32, at 5 (part of symposium issue on Politics and Prosecutors).

58. M.E. McGhee, "Prosecutorial Discretion," Georgetown Law Journal, 88 (2000): 1057-69, at 1057.

59. B.L. Gershman, "A Moral Standard for the Prosecutor's Exercise of the Charging Discretion." Fordham Urban Law Journal, 20 (1993): 513-30, at 513 n.3. Aside from the role that convictability plays in the decision to charge, both Miller, supra note 50, and Gottfredson and Gottfredson, supra note 56, recognized that there are reasons beyond legal concerns for not charging a suspect. For instance, although a prosecutor may decline to charge a suspect for legal reasons, such as insufficient evidence, a closer examination may indicate that the legal reason is merely a facade for an outright discretionary action. Specifically, a review of the case may reveal that there is sufficient legal 
evidence to convict; however, prosecution of the offender is "otherwise undesirable" in light of extralegal factors. Miller, supra note 50, at 155 . In fact, this "insufficient evidence" designation is often a convenient way out for the public prosecutor. Miller, supra note 50, at 156 .

60. Cole, supra note 44.

61. J. Schmidt and E.H. Steury, "Prosecutorial Discretion in Filing Charges in Domestic Violence Cases," in G.F. Cole and M.G. Gertz, eds., The Criminal Justice System: Politics and Policies, 7th ed. (Belmont, California: Wadsworth Publishing, 1998): 187201.

62. D. Hirschel and I.W. Hutchison, "The Relative Effects of Offense, Offender, and Victim Variables on the Decision to Prosecute Domestic Violence Cases,"Violence Against Women, 7, no. 1 (2001): 46-59; Miller, supra note 50; E.P. Baumer, S.F. Messner, and R.B. Felson, "The Role of Victim Characteristics in the Disposition of Murder Cases," Justice Quarterly, 17, no. 2 (2000): 281-307; L. Frohmann, "Convictability and Discordant Locales: Reproducing Race, Class, and Gender Ideologies in Prosecutorial Decisionmaking," Law \& Society Review, 31, no. 3 (1997): 53155; Schmidt and Steury, supra note 61.

63. Cole, supra notes 44, 50.

64. Frohmann, supra note 62; Spohn, Beichner, and DavisFrenzel, supra note 55.

65. Miller, supra note 50; D. Pritchard, "Homicide and Bargained Justice: The Agenda-Setting Effect of Crime News on Prosecutors," Public Opinion Quarterly, 50 (1986): 143-59; S.L. Haynie and E.A. Dover, "Prosecutorial Discretion and Press Coverage," American Politics Quarterly, 22, no. 3 (1994): 370-81.

66. Albonetti, supra note 57.

67. Frohmann, supra note 62, at 535 (citing R.M. Emerson and B.P. Paley, "Organizational Horizons and Complaint-Filing," in K. Hawkins, ed., The Uses of Discretion (New York: Oxford University Press, 1992)). See also L. Frohmann, "Discrediting Victims' Allegations of Sexual Assault: Prosecutorial Accounts of Case Rejections," Social Problems, 38, no. 2 (1991): 213-26, at 224.

68. D.O. Friedrichs, Trusted Criminals: White-collar Crime in Contemporary Society (Boston: Wadsworth Publishing Company, 1996): at 10.

69. G.S. Green, Occupational Crime, 2nd ed. (Chicago: Nelson-Hall Publishers, 1997): at 15; Friedrichs, supra note 68, at 102; Jesilow, Pontell, and Geis, supra note 21.

70. Jesilow, Pontell, and Geis, supra note 21, at 160.

71. Friedrichs, supra note 68, at xvii; Green, supra note 69, at xiii (quoting Gilbert Geis).

72. Friedrichs, supra note 68 , at $2,22$.

73. C.A. Albonetti, "Direct and Indirect Effects of Case Complexity, Guilty Pleas, and Offender Characteristics on Sentencing for Offenders Convicted of a White-Collar Offense Prior to Sentencing Guidelines, "Journal of Quantitative Criminology, 14, no. 4 (1998): 353-79, at 357; Jesilow, Pontell, and Geis, supra note 21; Ayers, Jr., and Frank, supra note 42.

74. Friedrichs, supra note 68, at 50-53. See also Johnson, "Disciplinary Actions and Pain Relief: Analysis of the Pain Relief Act," supra note 1, at 320-21.

75. Jesilow, Pontell, and Geis, supra note 21, at 161.

76. Green, supra note 69, at 184; Jesilow, Pontell, and Geis, supra note 21.

77. Jesilow, Pontell, and Geis, supra note 21, at 154.

78. Jesilow, Pontell, and Geis, supra note 21; Behr, supra note 9; P. Van Grunsven, "Criminal Prosecution of Health Care Providers for Clinical Mistakes and Fatal Errors: Is 'Bad Medicine' a Crime?," Journal of Health and Hospital Law, 29, no. 2 (1995): 107-20; Jost, supra note 11.
79. F.P. Bensel and B.D. Goldberg, "Prosecutions and Punitives for Malpractice Rise, Slowly," National Law Journal, January 22, 1996, at B7; Alpers, supra note 1; Van Grunsven, supra note 78; J. Liederbach et al., "The Criminalization of Physician Violence: Social Control in Transformation," Justice Quarterly, 18, no. 1 (2001): 141-70.

80. Van Grunsven, supra note 78, at 112; P. Van Grunsven, "Medical Malpractice or Criminal Mistake? An Analysis of Past and Current Criminal Prosecutions for Clinical Mistakes and Fatal Errors," DePaul Journal of Health Care, 2 (1997): 1-54, at 51; Liederbach et al., supra note 79, at 148-49.

81. Liederbach et al., supra note 79, at 145-50; Benson, Cullen, and Geis, supra note 42, at 364.

82. Jesilow, Pontell, and Geis, supra note 21, at 160.

83. Id. at 161. "U.S. Attorneys are extraordinarily kind to doctors, because even if they are crooks, theoretically they are still providing some useful services to the community."

84. Meisel, Jernigan, and Youngner, supra note 26.

85. Id. at 1092 .

86. Id. at 1090 .

87. Id.

88. Id. at 1092 .

89. Alpers, supra note 1 , at 308.

90. Id. at 311 .

91. Id. at 315 .

92. Id.

93. Id. at 311.

94. See Donaghue Medical Research Foundation, II. Assessment of Pain Management and Obstacles to Adequate Pain Management in Connecticut, at < http://www.aslme.org/research/ proposal pt2.php $>$ (last visited February 18, 2003).

95. D.A. Dillman, Mail and Internet Surveys: The Tailored Design Method, 2nd ed. (New York: John Wiley and Sons, Inc., 2000).

96. Meisel, Jernigan, and Youngner, supra note 26.

97. Alpers, supra note 1, at 315.

98. Fohr, supra note 26; Quill et al., supra note 1.

99. Whitecar, Jonas, and Clasen, supra note 5, at 761.

100. Fohr, supra note 26, at 316.

101. See Cantor, supra note 23; Alpers and Lo, supra note 23; Orentlicher and Caplan, supra note 22; Vacco v. Quill, 521 U.S. 793 (1997).

102. Pain Relief Promotion Act of 1999: Hearing on H.R. 2260 Before the Subcomm. on the Constitution of the House Comm. on the Judiciary, 106th Cong. (June 24, 1999) (written testimony of Walter R. Hunter, Associate National Medical Director, VistaCare Hospice), available at <http://www.house.gov/judiciary/ hunt0624.htm $>$.

103. Benson et al., supra note 42; Benson and Cullen, supra note 42; Ayers, Jr., and Frank, supra note 42; Liederbach et al., supra note 79.

104. Meisel, Jernigan, and Youngner, supra note 26; Gilson and Joranson, supra note 1; Benson and Cullen, supra note 42; Benson et al., supra note 42; Ayers, Jr., and Frank, supra note 42; Weinstein et al., supra note 3; Liederbach et al., supra note 79. Special thanks to Aaron Gilson, Ph.D., and Stuart Youngner, M.D., who helped further refine our thinking.

105. Steinbrook, supra note 22. See also S.J. Ziegler and N.P. Lovrich, Jr., Pain Relief and Prohibiting PAS: The Saga Continues (September 2001), Pain and the Law Website, at <http://www. painandthelaw.org/mayday/ziegler_lovrich_110101.php $>$.

106. Alpers, supra note 1.

107. Jacoby, The American Prosecutor: A Search for Identity, supra note 44.

108. See, e.g., $i d$.

109. Sees and Clark, supra note 5, at 258. 
110. Wilford et al., supra note 18.

111. M. Gaffney and N.P Lovrich, Jr., Perceptions of Crime: Differential Citizen Views of Problems of Public Order at the City and Neighborhood Level, paper presented at the Annual Meeting of the Academy of Criminal Justice Sciences, New Orleans, March 24, 2000. See also Benson and Cullen, supra note 42.

112. Prosecutor \#1: [I would refer] in conjunction with [the police investigation].

Prosecutor \#2: I would not only prosecute, but also refer to the state medical board.

Prosecutor \#3: Your question had us consider the state medical board in lieu of investigation. When I have had these cases [involving medical practice], we have had police and [the state medical board] investigate together. The police do not have the background for these investigations.

Prosecutor \#4: The questions asking if we would send matters to the medical board in lieu of police investigation are not well taken. We would likely [undertake] parallel investigations.

113. Prosecutor \#5: In our jurisdiction we have a significant drug problem, including prescription drug abuse. Most prescription drugs enter the criminal arena via forged prescriptions or sales by a patient. Additionally, a large number of prescription drugs are stolen from disabled and elderly patients and then diverted into the drug world.

Prosecutor \#6: In our state, there is a problem with the medical [board not] being vigilant enough. They need to be "harder lined." More severe sanctions, etc., would help with the "pill pushing" (some dole it out like candy). But you could not realistically prosecute most of this, nor would I want to. We don't have the resources nor do the cops.

Prosecutor \#7: Unless the doctor's conduct is extremely outrageous, I think it is not productive to prosecute doctors.

Prosecutor \#8: I realize that there is a problem [with health professionals who self-medicate] but also believe with treatment that these persons can be rehabilitated. Also realize that certain types of doctors should prescribe more pain-killers but are afraid to because of [their medical] license. The biggest problem [are patients who abuse the drugs and who are eventually able to find] older doctors (legal suppliers) who need the money.

Prosecutor \#9: Prescribing drug cases: for profit? [I have no anxiety when deciding to prosecute]. [Doctor has] lax controls? Punish for stupidity or do we want a knowing violation? If the physician is impaired [and diverting, I] would treat [the case] as if [it were motivated by] profit, but would treat differently for sentencing purposes. Evidence issues also present a problem hired experts on each side would describe typical dosages result in reasonable doubt? What about witnesses? Credibility issues are present because they may be addicted patients who are now cut off or co-defendants who assisted in street sales. If I get an undercover officer, that would be better, but [that would be] a problem if the jurisdiction is small.

114. Due to variation in the names of offenses among the states, we classified offenses using a generic classification scheme. Moreover, to avoid double counting, we counted only the highest offense when respondents provided lesser included offenses as alternatives (e.g., when both murder and manslaughter were offered, only murder was counted).

115. Prosecutor \#1: It would be referred to the state medical board in addition to, but never in lieu of, prosecution.... Don't know, need all the facts to make a determination.

Prosecutor \#2: I would need more information about the dosages and whether the administration [of the drug] met a criminal mental state.

Prosecutor \#5: Homicide or manslaughter. Note that Oregon is a PAS [physician-assisted suicide] state. If the patient was in [the] last hours of life, I would not file. Need more facts.

Prosecutor \#6: Need more information. What is a medically acceptable dosage.... Negligence? Was he [the doctor] unaware of the risk that he should have been aware of?.

Prosecutor \#7: [I don't know]. Some variables not provided — timing, the patient's prior use of narcotics, etc.

Prosecutor \#8: [I don't know]. We would need more facts.

Prosecutor \#16: It would be good to know if the doses administered were clearly beyond norms (something I assumed). This is an interesting and thought-provoking survey.

116. Prosecutor \#3: Wait for autopsy results.

Prosecutor \#4: Manslaughter would require "gross negligence" (would need numerous doctors to say so and that he would not have died then because he was dying anyway - soon?? [It is not that an offense has been committed, I just] do not think an offense could be proven.

Prosecutor \#9: Would depend upon information from medical experts.

Prosecutor \#10: Unless someone tells me this was negligent or reckless conduct, then would pursue further [I did not think an offense had been committed].

Prosecutor \#11: Depends on level of proof.

Prosecutor \#12: Homicide cases, especially those involving the members of the medical profession as defendants, are extremely complex and, depending on the facts, difficult to prove.

Prosecutor \#13: Difficult area that I have not yet had to address. My answers are wishy-washy mainly because I have not given much practical thought to the issue. In simple terms, I would likely not prosecute a doctor whose main purpose is to [relieve] a person's suffering provided they have not "actively" committed euthanasia.

Prosecutor \#14: [This may be] best answered through a coroner's inquest jury. [It] will arrive at a decision based on standards in the community.

Prosecutor \# 15: [A few of my family members] were hospice patients. My experience of their deaths completely determined my answers to your great questions. I was surprised about how strongly I feel on these issues. Because rational analysis played no part, I would have to refer this matter to another prosecutor in my office should the situation present itself.

117. We also drew a distinction between "uncertain" (the respondent was taking a middle ground as to whether the profession was effective or not in policing its own) and "do not know." Those choosing "uncertain" would correspond with a score of 4 along the seven-point scale, and those who did not know checked the box labeled "Don't Know."

118. See Van Grunsven, supra note 80; Liederbach et al., supra note 79 .

119. Benson and Cullen, supra note 42; Jesilow, Pontell, and Geis, supra note 21; Benson et al., supra note 42; and Ayers, Jr., and Frank, supra note 42.

120. We recognize that there are other parametric and nonparametric tests that we could have selected that would have contributed further to our analysis.

121. All variables were reviewed, and those which posed a risk of tautology were omitted.

122. See, e.g., P. Goodwin, "Oregon's Physician Assisted Suicide Law: An Alternative Viewpoint,” Archives of Internal Medicine, 157, (1997): 1642-44; S.J. Ziegler and N.P. Lovrich, Jr., Examining the Link Between Physical Pain and Requests for Hastened Death: Different Results or Different Values? (July 2, 2002), Pain and the Law Website, at <http://www.painandthelaw.org/ mayday/ziegler_070202.php>; R.J. Bonnie and B. Guyer, "Injury as a Field of Public Health: Achievements and Controversies," Journal of Law, Medicine \& Ethics, 30, no. 2 (2002): 267-80, at 278. 
123. Weinstein et al., supra note 3, at 481.

124. Greenwald and Narcessian, supra note 4, at 373.

125. Joranson and Gilson, supra note 7, at 217.

126. Gilson and Joranson, supra note 1, at 235.

127. Weinstein et al., supra note 3 , at 480 .

128. Gilson and Joranson, supra note 1, at 230.

129. Joranson and Gilson, supra note 7, at 215.

130. Greenwald and Narcessian, supra note 4, at 371.

131. Gilson and Joranson, supra note 1, at 230.

132. See Alpers, supra note 1; Jesilow, Pontell, and Geis, supra note 21 .

133. See notes 112 and 115 , supra.

134. Alpers, supra note 1 , at 315 .

135. Jesilow, Pontell, and Geis, supra note 21, at 161.

136. See Benson and Cullen, supra note 42; Benson, Cullen, and Geis, supra note 42.

137. See Martino, supra note 17. For a related context, see A.G. Lawthers et al., "Physicians' Perceptions of the Risk of Being Sued," Journal of Health Politics, Policy and Law, 17, no. 3 (1992): 463-82.

138. Gilson and Joranson, supra note 1. See also Hoover v. Agency for Health Care Admin., 676 So. 2d 1380 (Fla. Dist. Ct.
App. 1996).

139. J. Zaller and S. Feldman, "A Simple Theory of the Survey Response: Answering Questions versus Revealing Preferences," American Journal of Political Science, 36, no. 3 (1992): 579-616.

140. Alpers, supra note 1; Meisel, Jernigan, and Youngner, supra note 26.

141. Alpers, supra note 1.

142. Id. at 311.

143. See, e.g., Behr, supra note 9; Jesilow, Pontell, and Geis, supra note 21.

144. D.E. Joranson et al., "Pain Management, Controlled Substances, and State Medical Board Policy: A Decade of Change," Journal of Pain and Symptom Management, 23, no. 2 (2002): 138-47, at 144; Hyman, supra note 11, at 338.

145. For a comprehensive examination of state and federal policies relating to the medical use of opioids, see D.E. Joranson et al., Achieving Balance in Federal and State Pain Policy: A Guide to Evaluation (Madison: The Pain \& Policy Studies Group, University of Wisconsin Comprehensive Cancer Center, 2000), available at $<$ http://www.medsch.wisc.edu/painpolicy/eguide2000/index. html $>$. 